Article

\title{
Purification, Identification and Characterization of Antioxidant Peptides from Corn Silk Tryptic Hydrolysate: An Integrated In Vitro-In Silico Approach
}

\author{
Joe-Hui Ong ${ }^{1}\left(\mathbb{D}\right.$, Jiun-An Koh ${ }^{1}$, Hui Cao ${ }^{2}\left(\mathbb{D}\right.$, Sheri-Ann Tan ${ }^{3}$, Fazilah Abd Manan ${ }^{4}$, Fai-Chu Wong ${ }^{1,5}$ \\ and Tsun-Thai Chai ${ }^{1,5, *(D)}$ \\ 1 Department of Chemical Science, Faculty of Science, Universiti Tunku Abdul Rahman, \\ Kampar 31900, Malaysia; candy3997@1utar.my (J.-H.O.); jiunan30@1utar.my (J.-A.K.); \\ wongfc@utar.edu.my (F.-C.W.) \\ 2 College of Food Science and Technology, Guangdong Ocean University, Zhanjiang 524088, China; \\ hui_cao0830@yahoo.com \\ 3 Department of Bioscience, Faculty of Applied Sciences, Tunku Abdul Rahman University College, \\ Setapak, Kuala Lumpur 53300, Malaysia; tansw@tarc.edu.my \\ 4 Department of Biosciences, Faculty of Science, Universiti Teknologi Malaysia, Skudai, \\ Johor Bahru 81310, Malaysia; m-fazilah@utm.my \\ 5 Center for Agriculture and Food Research, Universiti Tunku Abdul Rahman, Kampar 31900, Malaysia \\ * Correspondence: chaitt@utar.edu.my; Tel.: +60-5-468-8888
}

\section{check for} updates

Citation: Ong, J.-H.; Koh, J.-A.; Cao, H.; Tan, S.-A.; Abd Manan, F.; Wong, F.-C.; Chai, T.-T. Purification, Identification and Characterization of Antioxidant Peptides from Corn Silk Tryptic Hydrolysate: An Integrated In Vitro-In Silico Approach. Antioxidants 2021, 10, 1822. https://doi.org/ 10.3390/antiox10111822

Academic Editors: Isabel Seiquer, José M. Palma and Daniel Franco Ruiz

Received: 4 October 2021

Accepted: 12 November 2021

Published: 17 November 2021

Publisher's Note: MDPI stays neutral with regard to jurisdictional claims in published maps and institutional affiliations.

Copyright: (c) 2021 by the authors. Licensee MDPI, Basel, Switzerland. This article is an open access article distributed under the terms and conditions of the Creative Commons Attribution (CC BY) license (https:// creativecommons.org/licenses/by/ $4.0 /)$.

\begin{abstract}
Corn silk (CS) is an agro-by-product from corn cultivation. It is used in folk medicines in some countries, besides being commercialized as health-promoting supplements and beverages. Unlike CS-derived natural products, their bioactive peptides, particularly antioxidant peptides, are understudied. This study aimed to purify, identify and characterize antioxidant peptides from trypsin-hydrolyzed CS proteins. Purification was accomplished by membrane ultrafiltration, gel filtration chromatography, and strong-cation-exchange solid-phase extraction, guided by $2,2^{\prime}$-azinobis(3-ethylbenzothiazoline-6-sulfonic acid) diammonium salt radical cation (ABTS ${ }^{\bullet+}$ ) scavenging, hydrogen peroxide scavenging, and lipid peroxidation inhibition assays. De novo sequencing identified 29 peptides (6-14 residues; 633-1518 Da). The peptides consisted of 33-86\% hydrophobic and 10-67\% basic residues. Molecular docking found MCFHHHFHK, VHFNKGKKR, and PVVWAAKR having the strongest affinity $(-4.7$ to $-4.8 \mathrm{kcal} / \mathrm{mol})$ to $\mathrm{ABTS}^{\bullet+}$, via hydrogen bonds and hydrophobic interactions. Potential cellular mechanisms of the peptides were supported by their interactions with modulators of intracellular oxidant status: Kelch-like ECH-associated protein 1, myeloperoxidase, and xanthine oxidase. NDGPSR (Asn-Asp-Gly-Pro-Ser-Arg), the most promising peptide, showed stable binding to all three cellular targets, besides exhibiting low toxicity, low allergenicity, and cell-penetrating potential. Overall, CS peptides have potential application as natural antioxidant additives and functional food ingredients.
\end{abstract}

Keywords: antioxidant; in silico; in vitro; mechanism; molecular docking; peptide; purification; Stigma maydis

\section{Introduction}

Corn silk (Stigma maydis) (CS) is the thread-like style at the top of an ear of corn. Although CS is discarded as an agricultural by-product worldwide, the value of CS as an herbal remedy has been recognized in the traditional medicines of some countries [1]. At present, CS health supplements and CS-based tea are also available to consumers. Phytochemically, CS is rich in flavonoids, which are responsible for some bioactivities of CS, such as antioxidant, anti-fatigue, and anti-hyperlipidemic [1]. In contrast to natural product exploration, the identification and characterization of CS-derived bioactive peptides are limited. CS consists of $17.6 \%$ of crude proteins by dry weight [1], hence it may be a potential 
source of bioactive peptides. To date, only antihypertensive [2] and anti-inflammatory [3] peptides were identified from CS, but there is no report of CS-derived antioxidant peptides. In our previous study, we found CS tryptic hydrolysate to be a more potent scavenger of hydrogen peroxide $\left(\mathrm{H}_{2} \mathrm{O}_{2}\right)$ and superoxide than glutathione $(\mathrm{GSH})$ and carnosine, two well-established peptidic antioxidants. Moreover, CS tryptic hydrolysate was more effective than the two aforementioned antioxidants in protecting human red blood cells from oxidative injury [4]. Nevertheless, the identity of the antioxidant peptides in the hydrolysate has not been unraveled.

Antioxidant peptides derived from food and agricultural waste/by-products are recognized for their potential applications as food additives, functional food, health-promoting supplements, and lead compounds for drug discovery. In the food industry, such peptidic antioxidants of natural origin could be substitutes for synthetic antioxidants, which have raised concerns about health risks. Besides attenuating food oxidation, antioxidant peptides could also serve as curative or preventive agents of reactive oxygen species (ROS)mediated diseases, supporting the application of such peptides in functional food and health supplement formulation [5]. Antioxidant peptides could alleviate cellular oxidative damage by scavenging free radicals and/or by regulating the cellular production of antioxidants or oxidants. The Keap1/Nrf2 pathway is a major pathway that modulates cellular antioxidant responses, which can be activated by antioxidant peptides [6]. Under oxidative stress, nuclear factor erythroid 2-related factor 2 (Nrf2) bound to Kelch-like ECH-associated protein 1 (Keap1) will detach and migrate to the nucleus, where it activates the expression of antioxidant genes [7]. By contrast, myeloperoxidase (MPO) and xanthine oxidase (XO) are associated with cellular ROS production. Antioxidant peptides isolated from fish skin gelatin hydrolysate alleviated oxidative injury in mice by inhibiting MPO, besides activating the Nrf2 to upregulate the expression of antioxidant enzymes [8]. Antioxidant peptides derived from mackerel meat, egg white, and tuna backbone protein were also demonstrated as potent $\mathrm{XO}$ inhibitors [9].

In this study, we adopted an integrated in vitro-in silico approach to purify, identify, and characterize antioxidant peptides from a CS tryptic hydrolysate. Purification using membrane ultrafiltration (UF), gel filtration chromatography (GFC), and strongcation-exchange solid-phase extraction (SCX-SPE) were guided by antioxidant assays including 2,2'-azino-bis(3-ethylbenzothiazoline-6-sulfonic acid) diammonium salt radical cation $\left(\mathrm{ABTS}^{\bullet+}\right.$ ) scavenging, $\mathrm{H}_{2} \mathrm{O}_{2}$ scavenging, and lipid peroxidation inhibition assays. The peptides identified by de novo peptide sequencing were subjected to in silico analyses. Physicochemical properties of the peptides were analyzed to clarify the relationship between amino acid composition and the antioxidant potential of the CS hydrolysatederived peptides. Toxicity, allergenicity, and cell-penetrating potential of the peptides were predicted. Moreover, molecular docking simulation was performed to investigate the antioxidant mechanisms of the peptides in the context of their intermolecular interactions with $\mathrm{ABTS}^{\bullet+}$ and with the modulators of cellular oxidant status Keap1, MPO, and XO.

\section{Materials and Methods}

\subsection{Materials and Reagents}

CS was provided by Mr. Khuan Thean Ang, the owner of a local corn plantation located at Pinang Tunggal, Pulau Pinang, Malaysia. O-phthalaldehyde (OPA) and trypsin (from hog pancreas, $1539 \mathrm{U} / \mathrm{mg}$ ) were purchased from Nacalai Tesque Inc. (Kyoto, Japan). GSH was purchased from Sigma-Aldrich (Saint Louis, MO, USA). Lecithin (egg) and trichloroacetic acid were purchased from Fisher Scientific (Waltham, MA, USA). Copper (II) acetate monohydrate and $\mathrm{H}_{2} \mathrm{O}_{2}$ were purchased from $\mathrm{R} \& \mathrm{M}$ Chemicals (London, UK). Formic acid, acetonitrile, 2,2'-azino-bis(3-ethylbenzthiazoline-6-sulfonic acid) (ABTS) diammonium salt, thiobarbituric acid, and UF centrifugal filter unit with $3 \mathrm{kDa}$ molecular weight cut-off (MWCO) were purchased from Merck (Darmstadt, Germany). Sephadex G25 resins were purchased from GE Healthcare (Danderyd, Sweden). Solid-phase extraction (SPE) cartridges STRATA SCX (sorbent mass: $1000 \mathrm{mg}$; volume: $6 \mathrm{~mL}$ ) and STRATA C18-E 
(sorbent mass: $500 \mathrm{mg}$; volume: $3 \mathrm{~mL}$ ) were purchased from Phenomenex Inc. (Torrance, CA, USA). All the reagents and solvents were of analytical grade.

\subsection{Preparation of CS Protein Isolate and Hydrolysate}

CS protein isolate and 1-h trypsin hydrolysate $(\mathrm{T} 1 \mathrm{H})$ were prepared as previously described [4]. Peptide contents were determined by using the OPA assay [10].

\subsection{Purification of Antioxidant Peptides from $\mathrm{T} 1 \mathrm{H}$}

T1H was purified by using UF, GFC, and SCX-SPE as previously reported [11], with modifications. $\mathrm{T} 1 \mathrm{H}$, dissolved in deionized water, was fractionated by using UF centrifugal filter units (MWCO $3 \mathrm{kDa}$ ). Both the retentate and permeate fractions, designated as $>3 \mathrm{kDa}$ UF and $<3 \mathrm{kDa} \mathrm{UF}$, were collected and lyophilized. The $<3 \mathrm{kDa}$ UF fraction was further separated on a Sephadex G-25 chromatographic column $(1.6 \times 70.0 \mathrm{~cm}$, Sigma-Aldrich, Saint Louis, MO, USA), eluted with deionized water (flow rate $0.6 \mathrm{~mL} / \mathrm{min}$ ). The resultant fractions were monitored spectrophotometrically at $280 \mathrm{~nm}$ and subsequently combined into three pooled fractions designated as GF-I, GF-II, and GF-III. The lyophilized GF-III fraction was next purified by using a STRATA SCX cartridge (Phenomenex Inc., Torrance, CA, USA) as described previously [11].

Protein contents of the UF fractions were determined by using the Bradford reagent (Bio Basic Inc., Markham, Canada) [12]. Quantification of peptides in fractions collected during the aforementioned purification steps were accomplished with the OPA assay [10]. Antioxidant activities were evaluated by using ABTS ${ }^{\bullet+}$ and $\mathrm{H}_{2} \mathrm{O}_{2}$ scavenging assays, as well as lipid peroxidation inhibition assay as described below.

\subsection{Identification of Purified Peptides}

Following the SCX-SPE purification step, the resultant desalted 0, 20, and $200 \mathrm{mM} \mathrm{KCl}$ fractions were selected for de novo peptide sequencing based on a liquid chromatographytandem mass spectrometry (LC-MS/MS) system (Thermo Fisher Scientific, Waltham, MA, USA). The analysis was performed at the Proteomics Laboratory, Malaysia Genome and Vaccine Institute, National Institutes of Biotechnology Malaysia. The Ultimate 3000 RSLC nano-high-performance liquid chromatography system (Thermo Fisher Scientific, Waltham, MA, USA), coupled to an Orbitrap Fusion mass spectrometer (Thermo Fisher Scientific, Waltham, MA, USA), was used to analyze the samples. Peptides were sequenced by using the DeNovoGUI Software (Version 1.16.2, Max Planck Institute, Munich, Germany), based on the MS/MS spectral data collected.

\subsection{Determination of Antioxidant Activities}

The $\mathrm{ABTS}^{\bullet+}$ scavenging activity of peptide samples was determined by using a decolorization assay, as previously reported [11]. The $\mathrm{H}_{2} \mathrm{O}_{2}$ scavenging activity was evaluated as previously outlined [13], except that $600 \mu \mathrm{L} \mathrm{H}_{2} \mathrm{O}_{2}(40 \mathrm{mM})$ was included in the reaction mixture. The protective effect against lipid peroxidation was estimated by using a lecithin liposome model [4]. Briefly, a mixture containing the test sample, lecithin, and copper (II) acetate monohydrate was incubated in darkness at $37^{\circ} \mathrm{C}$ for 24 and $48 \mathrm{~h}$, followed by monitoring of absorbance at 532 and $600 \mathrm{~nm}$. Thiobarbituric acid reactive species (TBARS) levels were calculated and expressed as $\mu \mathrm{M}$ malondialdehyde (MDA) equivalents. GSH was used as a reference antioxidant in the three antioxidant assays.

\subsection{In Silico Analysis}

\subsubsection{Modelling of Peptide Structures}

The three-dimensional (3D) conformations of peptides identified by the LC-MS/MS experiment were modeled with PEP-FOLD 3.5 (https: / / bioserv.rpbs.univ-paris-diderot. $\mathrm{fr} /$ services/PEP-FOLD3) (access date: 12 June 2021). PEP-FOLD 3.5 is an online tool for the de novo prediction of peptide structures from amino acid sequences [14-16]. The tasks were set to allow 200 simulation runs and the conformation models were evaluated based 
on sOPEP energy scores. The best-scored model for each peptide was saved in the Protein Data Bank (PDB) format and used in molecular docking analysis.

\subsubsection{Prediction of Antioxidant Peptides and Docking to ABTS ${ }^{\bullet+}$}

Peptide sequences identified by the LC-MS/MS experiment were submitted to the AnOxPePred web server (https:/ / services.healthtech.dtu.dk/service.php?AnOxPePred1.0) [17] (accessed on 18 June 2021) to predict free radical scavenging activities. Based on their scores, selected peptides were used in molecular docking analysis.

For docking, the 3D conformer of ABTS (PubChem CID: 5360881) was downloaded from PubChem (https:/ / pubchem.ncbi.nlm.nih.gov) [18] (access date: 15 June 2021) in the Structure Data File (SDF) format and converted to the PDB format by using the BIOVIA Discovery Studio Visualizer (BIOVIA, Dassault Systèmes, BIOVIA Discovery Studio Visualizer, Version 20.1.0.192, San Diego, CA, USA: Dassault Systèmes, 2020). The PDB coordinates of ABTS were processed for energy minimization by using the GlycoBioChem PRODRG2 server (http:/ / davapc1.bioch.dundee.ac.uk/cgi-bin/prodrg) [19] (access date: 15 June 2021). The resultant PDB file was prepared as a ligand in the PDBQT format with AutoDockTools 1.5.6 (The Scripps Research Institute, La Jolla, CA, USA) [20,21]. Peptides were prepared for docking by adding Kollman charges and polar hydrogens by using AutoDockTools 1.5.6, saved in the PDBQT format. Docking simulation was performed by using default settings on Webina 1.0.2 (https:/ / durrantlab.pitt.edu/webina) [22] (access date: 16 June to 26 October 2021). Coordinates of docking-box center and box size are provided in Table S1. Through preliminary optimization trials, the box settings were chosen to center on the peptide structure being docked, ensuring the box was large enough to enclose the whole peptide. The two-dimensional (2D) diagrams of peptide-ABTS ${ }^{\bullet+}$ interactions were visualized by using LigPlot+ v.2.2 (EMBL-EBI, Cambridge, UK) [23,24].

\subsubsection{Docking-Based Screening of Potential Inhibitors of Keap1, MPO, and XO}

The X-ray crystal structures of murine Keap1 in complex with inhibitor RA839 (PDB code: 5CGJ) [7], human MPO bound to inhibitor 7-benzyl-1H-[1,2,3]triazolo [4,5-b]pyridin5 -amine (PDB code: 6WYD) [25], and bovine XO complexed with quercetin (PDB code: 3NVY) [26] were downloaded from the RCSB Protein Data Bank (https://www.rcsb. org) $[27,28]$ (access date: 19 June 2021). Proteins and the bound ligands were separated by using BIOVIA Discovery Studio Visualizer (Dassault Systèmes, San Diego, CA, USA). The three proteins were prepared as receptors, whereas the CS peptides to be docked were prepared as ligands by using AutoDockTools 1.5.6, all saved in the PDBQT format as previously described [29]. The docking of CS peptides to these three protein targets was performed by using Webina 1.0.2 (University of Pittsburgh, Pittsburgh, PA, USA). To validate our docking protocol, redocking of the crystallographic ligands to the respective proteins were performed and the root mean square deviation (RMSD) were obtained. Coordinates of the docking-box center and box size, as well as the RMSD values obtained, are provided in Table S1. Through preliminary trials, the box settings were chosen by centering on the original position of the co-crystalized ligand and then optimized to achieve an RMSD of $<2 \AA$ in the redocked co-crystalized ligand. The 3D diagrams of protein-peptide docking models were visualized with BIOVIA Discovery Studio Visualizer. The 2D diagrams of protein-peptide interaction were prepared with LigPlot+ v.2.2 [23,24].

2.6.4. Prediction of Physicochemical Properties, Toxicity, Allergenicity, and Cell-Penetrating Potential

Physicochemical properties of peptides were predicted by using the Peptides Package in R (https://rdrr.io/snippets/) [30] (access date: 26 June 2021). The online tool ToxinPred (https:/ / webs.iiitd.edu.in/raghava/toxinpred/index.html) (access date: 24 June to 5 July 2021) was used to predict the toxicity of selected peptides. The prediction was done based on a support vector machine with a default threshold of 0.0 [31]. Subsequently, AllerTOP v.2.0 (https:/ / www.ddg-pharmfac.net/AllerTOP) (access date: 24 June to 5 July 2021) was used for allergenicity prediction [32]. Prediction of cell-penetrating potential was 
performed with BChemRF-CPPred (http:/ / comptools.linc.ufpa.br/BChemRF-CPPred/) (access date: 24 June to 5 July 2021), by using options FC-3 and Model Version 2.0 in the setting [33].

\subsection{Statistical Analysis}

Data were presented as mean \pm standard errors $(n=3)$. Statistical analysis was performed by using the SAS University Edition Software (Version 9.4, SAS Institute, Cary, NC, USA). The data were first analyzed by using the one-way ANOVA test. Subsequent multiple comparisons of the means were done by using Tukey's test at a 95\% confidence interval $(p<0.05)$.

\section{Results and Discussion}

\subsection{Purification of T1H by UF}

T1H was separated by UF, yielding two UF fractions. The $>3 \mathrm{kDa}$ fraction exhibited stronger antioxidant activity than the $<3 \mathrm{kDa}$ fraction based on their $\mathrm{EC}_{50}$ for $\mathrm{ABTS}^{\bullet+}$ (28.4 and $45.6 \mu \mathrm{g}$ dry mass (DM)/mL, respectively) and $\mathrm{H}_{2} \mathrm{O}_{2}(174.5$ and $461.7 \mu \mathrm{g} \mathrm{DM} / \mathrm{mL}$, respectively) scavenging activities (Figure $1 \mathrm{C}, \mathrm{D}$ ). TBARS value of the negative control increased from 0.7 to $1.6 \mu \mathrm{M}$ MDA equivalents after incubation of the lecithin liposomes from 24 to $48 \mathrm{~h}$, indicating an increase in lipid peroxidation. As revealed by the TBARS values, treatment with $0.5 \mathrm{mg} \mathrm{DM} / \mathrm{mL}$ of $>3 \mathrm{kDa}$ and $<3 \mathrm{kDa}$ fractions inhibited lipid peroxidation by $22 \%$ and $16 \%$ after $24 \mathrm{~h}$, and by $64 \%$ and $50 \%$ after $48 \mathrm{~h}$, respectively (Figure 1E). Our results are concordant with previous observations on the antioxidant activities of the UF fractions of fennel seed hydrolysate [34]. In theirs and this study, the superiority of the $>3 \mathrm{kDa}$ fraction in scavenging radicals relative to the $<3 \mathrm{kDa}$ fraction was observed. This may be attributed, in part, to the presence of large compounds, such as long peptides, partially degraded proteins, or other components with antioxidant properties in the $>3 \mathrm{kDa}$ fraction. In fact, the protein content of the $>3 \mathrm{kDa}$ fraction was 8 -fold higher than that of the $<3 \mathrm{kDa}$ fraction (Figure 1A). By contrast, the $<3 \mathrm{kDa}$ fraction was peptide-rich, with peptide content 5 -fold greater than the $>3 \mathrm{kDa}$ fraction (Figure 1B).

Notably, the $<3 \mathrm{kDa}$ fraction was comparable or superior to T1H in scavenging ABTS ${ }^{\bullet+}$ and repressing lipid peroxidation, based on activity data reported in our previous study [4]. This implies that at least part of the antioxidant activities exhibited by $\mathrm{T} 1 \mathrm{H}$ could be attributed to the presence of antioxidant peptides in the hydrolysate. The $<3 \mathrm{kDa}$ fraction was weaker than antioxidant tripeptide $\mathrm{GSH}\left(\mathrm{EC}_{50} 6.7 \mu \mathrm{g} \mathrm{DM} / \mathrm{mL}\right)$ as an $\mathrm{ABTS}^{\bullet+}$ scavenger but 3-fold stronger than GSH ( $\mathrm{EC}_{50} 1378.7 \mu \mathrm{g} \mathrm{DM} / \mathrm{mL}$ ) as $\mathrm{H}_{2} \mathrm{O}_{2}$ scavenger. $\mathrm{H}_{2} \mathrm{O}_{2}$ is an ROS molecule that can diffuse through biological membranes and convert to highly reactive hydroxyl radicals in the body cells [5]. Hence, the $<3 \mathrm{kDa}$ UF fraction likely contained antioxidant peptides with the ability to scavenge biologically relevant ROS. In this study, a time-dependent increase in the lipid peroxidation inhibitory activity of the UF fractions was observed (Figure 1E). This observation agrees with a previous study that compared the ability of corn gluten meal hydrolysates to inhibit lipid peroxidation in a ground pork system following $8 \mathrm{~h}$ and $16 \mathrm{~h}$ of treatment [35]. Our result showed that the lipid peroxidation inhibitory effects of the CS peptides could persist up to $48 \mathrm{~h}$. Low molecular weight (MW) peptides are desirable because they could be more easily absorbed by the body compared to high MW peptides [5]. Thus, the peptide-enriched $<3 \mathrm{kDa}$ fraction was selected for further purification. 


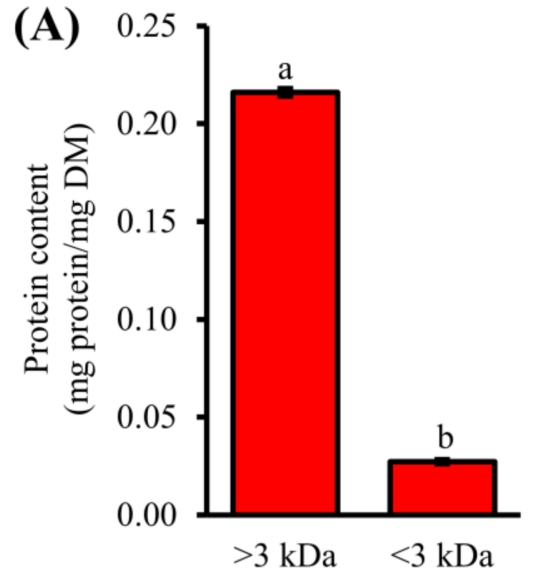

UF fractions

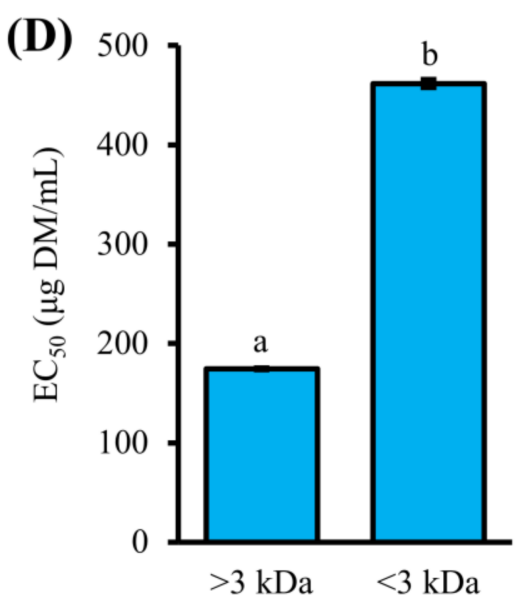

UF fractions

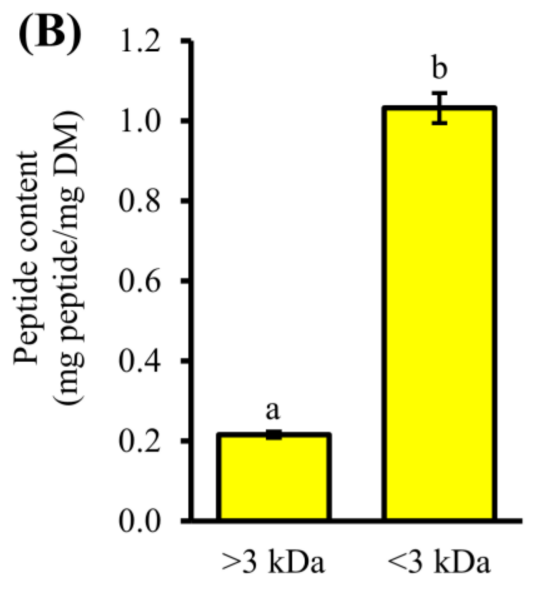

UF fractions



Figure 1. (A) Protein content, (B) peptide content, (C) 2,2'-azino-bis(3-ethylbenzothiazoline-6-sulfonic acid) diammonium salt radical cation $\left(\mathrm{ABTS}^{\bullet+}\right)$ scavenging activity and (D) hydrogen peroxide $\left(\mathrm{H}_{2} \mathrm{O}_{2}\right)$ scavenging activity of ultrafiltration (UF) fractions. (E) Thiobarbituric acid reactive species (TBARS) values of negative control and UF fractions tested at $0.5 \mathrm{mg}$ dry mass $(\mathrm{DM}) / \mathrm{mL}$. For each bar chart, data are mean \pm standard errors $(n=3)$. Mean values denoted by different superscript letters are significantly different $(p<0.05)$ according to Tukey's test.

\subsection{Purification of $<3 k D a$ Fraction by GFC}

Purification by GFC resulted in three pooled fractions: GF-I, GF-II, and GF-III (Figure 2A). Among the three, GF-I exhibited the strongest effects in ABTS $^{\bullet+}$ scavenging activity (Figure 2C). GF-I possibly comprised more non-aromatic peptide residues with radical scavenging activity, such as Leu and Pro [36] than the other two fractions. Meanwhile, GF-III showed the highest $\mathrm{H}_{2} \mathrm{O}_{2}$ scavenging activity among the three pooled fractions (Figure 2D). All three pooled GFC fractions could dampen the time-dependent increase in lipid peroxidation in the liposome model at $0.1 \mathrm{mg}$ peptide/mL, with $26-35 \%$ inhibition of TBARS formation after $48 \mathrm{~h}$ (Figure 2E), although their activities were significantly lower than that of GSH (57\% inhibition after $48 \mathrm{~h})$. The peptide content of GF-III ( $0.68 \mathrm{mg}$ peptide/mg DM) was 3.5-fold greater than those of GF-I and GF-II (Figure 2B). When compared to GF-III, 3.5-fold higher DM of GF-I and GF-II was required to achieve the standardized peptide concentration used for evaluating the lipid peroxidation inhibitory activity depicted in Figure 2E. It can be anticipated that when expressed in terms of DM, the lipid peroxidation inhibitory activity of GF-III may exceed that of GF-I. Thus, we also analyzed the lipid peroxidation inhibitory activity of the three pooled fractions at $0.5 \mathrm{mg} \mathrm{DM} / \mathrm{mL}$. As expected, among the three fractions, GF-III showed the strongest inhibition of TBARS 
formation, with $26 \%$ and $51 \%$ inhibition after 24 and $48 \mathrm{~h}$, respectively (Figure $2 \mathrm{~F}$ ). The antioxidant activity of GF-III could be owing to its relatively high absorbance at $280 \mathrm{~nm}$ (Figure 2A), which suggests an abundance of aromatic amino acid residues (e.g., Phe, Tyr, and Trp) in the pooled fraction. In keeping with this study, a previous study on Chinese chestnut also found that the GFC fraction with the most prominent absorbance at $280 \mathrm{~nm}$ had the highest antioxidant activity among all GFC fractions [37].


Figure 2. Purification of the $<3 \mathrm{kDa}$ fraction by gel filtration chromatography (GFC). (A) Elution profile, (B) peptide content, (C) ABTS $^{\bullet+}$ scavenging activity (at $30 \mu$ g peptide $/ \mathrm{mL}$ ), and (D) $\mathrm{H}_{2} \mathrm{O}_{2}$ scavenging activity (at $150 \mu \mathrm{g}$ peptide/mL) of pooled GFC fractions. TBARS values of negative control and GFC fractions (E) at $0.1 \mathrm{mg}$ peptide $/ \mathrm{mL}$ and (F) at $0.5 \mathrm{mg} \mathrm{DM} / \mathrm{mL}$. Data are mean \pm standard errors $(n=3)$. For each bar chart, mean values denoted by different superscript letters are significantly different $(p<0.05)$ according to Tukey's test.

In our GFC experiment, GF-II (intermediate molecular size) had the lowest antioxidant activity, whereas GF-I (greatest molecular size) and GF-III (smallest molecular size) had relatively higher antioxidant activities. Hence, our results suggest that the antioxidant 
potential of the GFC fractions is not directly related to their molecular size. This is in agreement with the lack of explicit relationship between antioxidant activity and molecular size among 81 corn gluten meal peptide fractions collected in a GFC experiment [38]. On the other hand, peptide content data and the different trends in the lipid peroxidation inhibitory activities of the pooled fractions when tested based on DM and peptide mass pointed to the presence of non-peptide constituents in the GFC fractions. Thus, further purification was desirable. Considering that GF-III was the richest in peptide content and to discover peptides containing aromatic amino acid residues from $\mathrm{T} 1 \mathrm{H}$, we proceeded to perform purification on GF-III.

\subsection{Purification of GF-III by SCX-SPE}

GF-III was further purified by SCX-SPE, producing six SPE fractions. As shown in Figure 3A, most of the peptide constituents of GF-III were found in $50 \mathrm{mM} \mathrm{KCl}$ fraction (0.9 mg peptide/ $\mathrm{mL}$ ), which was 22-118 times greater than the other five SPE fractions. The $50 \mathrm{mM} \mathrm{KCl}$ fraction showed relatively low or no ABTS ${ }^{\bullet+}$ and $\mathrm{H}_{2} \mathrm{O}_{2}$ scavenging activities at the peptide concentrations tested (Figure 3B,C). Our result suggests that SCXSPE has partitioned most of the non-antioxidant peptides and/or peptides with weak antioxidant activity into the $50 \mathrm{mM} \mathrm{KCl}$ fraction.
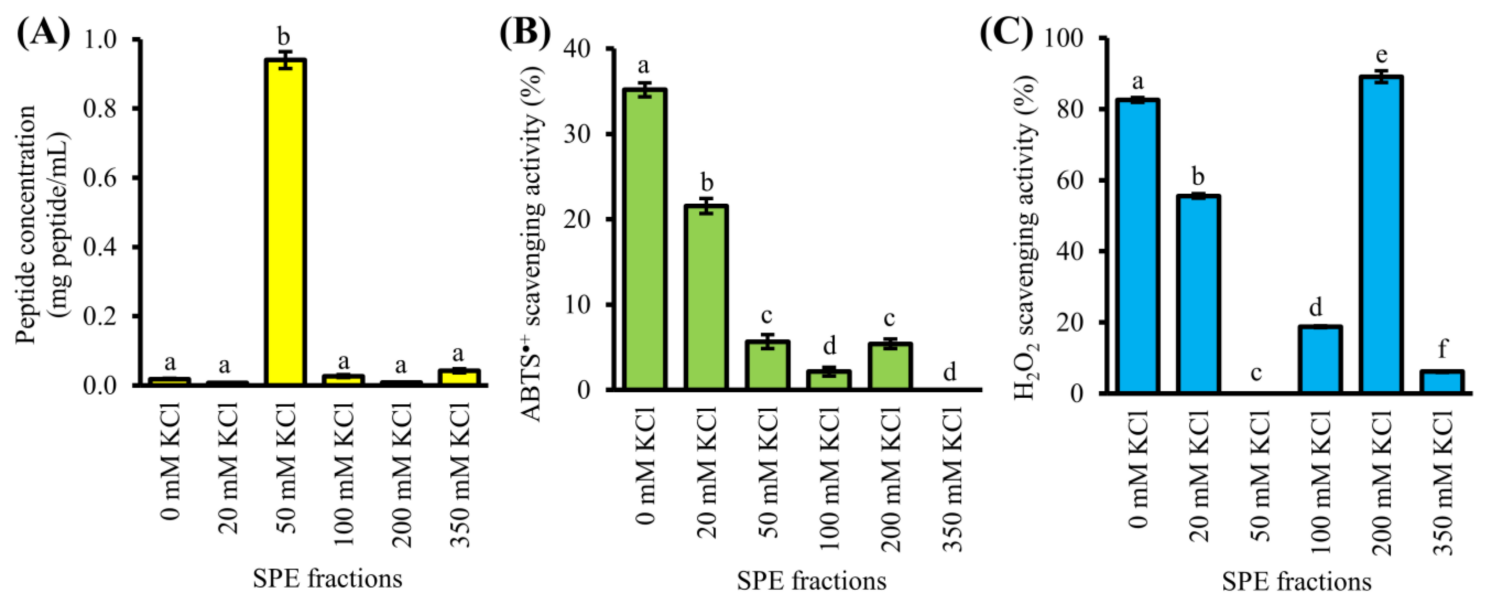

Figure 3. Purification of the GF-III fraction by strong-cation-exchange solid-phase extraction (SPE). (A) Peptide concentration, (B) ABTS $^{\bullet+}$ scavenging activity (at $0.7 \mu$ g peptide $/ \mathrm{mL}$ ), and (C) $\mathrm{H}_{2} \mathrm{O}_{2}$ scavenging activity (at $10 \mu \mathrm{g}$ peptide/mL) of SPE fractions. Data are mean \pm standard errors $(n=3)$. For each bar chart, mean values denoted by different superscript letters are significantly different $(p<0.05)$ according to Tukey's test.

The effectiveness of SCX-SPE in concentrating the antioxidant peptides into single fractions were also evident, as affirmed by the enhancement in antioxidant activity after the SPE step. Briefly, $30 \mu \mathrm{g}$ peptide/mL of GF-III scavenged $57 \%$ of $\mathrm{ABTS}^{\bullet+}$ (Figure 2C). After the purification of GF-III by SCX-SPE, the resultant 0 and $20 \mathrm{mM} \mathrm{KCl}$ fractions scavenged $35 \%$ and $22 \%$ ABTS $^{\bullet+}$ at a 43 -fold lower concentration $(0.7 \mu$ g peptide $/ \mathrm{mL})$, respectively (Figure 3B). By estimation, the 0 and $20 \mathrm{mM} \mathrm{KCl}$ fractions may be 26 -fold and 17-fold stronger than GF-III as ABTS ${ }^{\bullet+}$ scavengers, respectively. Other studies also showed 33\% [39] and 44\% [34] improvement in the ABTS ${ }^{\bullet+}$ scavenging activity of a peptide fraction purified by the SCX-SPE. The potency of the 0 and $20 \mathrm{mM} \mathrm{KCl}$ fractions over the other SPE fractions as $\mathrm{ABTS}^{\bullet+}$ scavenger may be attributed to the presence of negatively charged amino acids (e.g., Glu) [40] or proton-donating amino acids (e.g., Trp and Gln) [38] The presence of such residues may impart antioxidant activity to peptides by transferring electrons or protons to free radicals [36]. For instance, rapeseed peptides predominantly made up of Glu (19.5\%) were reported to have potent radical scavenging activity [40]. Corn gluten meal-derived peptides made up of $67 \%$ of Trp and Gln displayed high ABTS ${ }^{\bullet+}$ scavenging activity [38]. 
A similar improvement in the antioxidant activity of SPE fractions following SCX-SPE was revealed by the $\mathrm{H}_{2} \mathrm{O}_{2}$ scavenging assay. For example, $150 \mu \mathrm{g}$ peptide/mL of GF-III scavenged $65 \% \mathrm{H}_{2} \mathrm{O}_{2}$ (Figure 2D). In contrast, at a 15-fold lower concentration (10 $\mu \mathrm{g}$ peptide/mL), the 0 and $200 \mathrm{mM} \mathrm{KCl}$ fractions scavenged more than $80 \%$ of $\mathrm{H}_{2} \mathrm{O}_{2}$ (Figure $3 \mathrm{C}$ ). The $20 \mathrm{mM} \mathrm{KCl}$ fraction also scavenged $56 \% \mathrm{H}_{2} \mathrm{O}_{2}$ when tested at $10 \mu \mathrm{g}$ peptide $/ \mathrm{mL}$. Thus, based on theoretical calculations, our results imply a 13-21-fold improvement in the $\mathrm{H}_{2} \mathrm{O}_{2}$ scavenging activity of the 0,20 , and $200 \mathrm{mM} \mathrm{KCl}$ fractions resulting from the purification of GF-III by using SCX-SPE. Altogether, the 0,20 , and $200 \mathrm{mM} \mathrm{KCl}$ fractions potentially contained potent antioxidant peptides; thus, they were taken to peptide sequencing.

\subsection{Identification and Characterization of Antioxidant Peptides}

LC-MS/MS analysis identified 29 peptide sequences comprising 6-14 residues (633.33 to $1517.81 \mathrm{Da}$ ) from the 0,20 , and $200 \mathrm{mM} \mathrm{KCl}$ fractions (Table 1). This range of peptide masses agrees with the observation that the molecular masses of food-derived antioxidant peptides commonly range between 500-1800 Da [36]. Twenty-three of the 29 peptides contain $11-56 \%$ aliphatic amino acid residues (Table 1$)$. Such residues are responsible for the thermal stability of proteins [30]. Two thermal-stable antioxidant peptides WAFAPA and MYPGLA that were identified from the blue-spotted stingray, for instance, are composed of $50 \%$ and $33 \%$ of aliphatic residues, respectively [11]. Based on the comparison of the aliphatic index, 10 of the 29 peptides were likely superior to both WAFAPA and MYPGLA in terms of thermal stability (Table 1). The discovery of such peptides also supports our previous observation of the thermal stability of $\mathrm{T} 1 \mathrm{H}$, the protein hydrolysate from which the 29 peptides were purified. $\mathrm{T} 1 \mathrm{H}$ retained its radical scavenging and ferric reducing activity at temperatures up to $100{ }^{\circ} \mathrm{C}$ [4]. These CS peptides that are likely to be thermal-stable can thus be utilized as alternatives for food additives to address the concerns regarding the food processing heat treatment.

Table 1. Physicochemical properties of the peptides identified from the 0,20 , and $200 \mathrm{mM} \mathrm{KCl}$ fractions.

\begin{tabular}{|c|c|c|c|c|c|c|c|c|}
\hline $\begin{array}{c}\text { SPE } \\
\text { Fractions }\end{array}$ & Peptides & $\begin{array}{c}\text { Measured } \\
m / z \\
{[\mathrm{M}+2 \mathrm{H}]^{2}}\end{array}$ & $\begin{array}{c}\text { Molecular } \\
\text { Mass } \\
\text { (Da) }^{a}\end{array}$ & $\begin{array}{c}\text { Aromatic } \\
\text { Residues } \\
\qquad(\%)^{b}\end{array}$ & $\begin{array}{c}\text { Basic } \\
\text { Residues } \\
(\%)^{b}\end{array}$ & $\begin{array}{c}\text { Hydrophobic } \\
\text { Residues } \\
(\%)^{b}\end{array}$ & $\begin{array}{c}\text { Aliphatic } \\
\text { Residues } \\
(\%)^{b}\end{array}$ & $\begin{array}{l}\text { Aliphatic } \\
\text { Index }\end{array}$ \\
\hline \multirow{15}{*}{$0 \mathrm{mM} \mathrm{KCl}$} & KRYFKR & 449.28 & 896.57 & 33 & 67 & 33 & 0 & 0 \\
\hline & PRVRVAGR & 455.79 & 909.58 & 0 & 38 & 63 & 38 & 85 \\
\hline & PVVWAAKR & 463.79 & 925.57 & 13 & 25 & 75 & 50 & 98 \\
\hline & QVASGPLQR & 478.28 & 954.55 & 0 & 11 & 56 & 33 & 87 \\
\hline & MAPRTPRK & 478.78 & 955.57 & 0 & 38 & 50 & 13 & 13 \\
\hline & NKVVKLMR & 494.31 & 986.62 & 0 & 38 & 50 & 38 & 121 \\
\hline & KVPLAVFSR & 508.82 & 1015.64 & 11 & 22 & 67 & 44 & 119 \\
\hline & LKKGSPLKR & 513.84 & 1025.69 & 0 & 44 & 44 & 22 & 87 \\
\hline & FQLKPVFR & 517.82 & 1033.63 & 25 & 25 & 63 & 25 & 85 \\
\hline & THAVKGVVHK & 538.34 & 1074.67 & 20 & 40 & 50 & 40 & 97 \\
\hline & YTWKFKGR & 543.31 & 1084.61 & 38 & 38 & 50 & 0 & 0 \\
\hline & ARVPQQSYR & 552.80 & 1103.61 & 11 & 22 & 44 & 22 & 43 \\
\hline & VHFNKGKKR & 557.34 & 1112.69 & 22 & $\overline{56}$ & 33 & 11 & 32 \\
\hline & TAPLSSKALKR & 586.37 & 1170.73 & 0 & 27 & 45 & 36 & 89 \\
\hline & FSCPLVMKGPNGLR & 759.91 & 1517.81 & 7 & 14 & 71 & 21 & 76 \\
\hline \multirow{4}{*}{$20 \mathrm{mM} \mathrm{KCl}$} & RHGSGR & 335.18 & 668.37 & 17 & 50 & 33 & 0 & 0 \\
\hline & NMVPGR & 337.17 & 672.34 & 0 & 17 & 67 & 17 & 48 \\
\hline & FMFFVYK & 491.25 & 980.50 & 57 & 14 & 86 & 14 & 41 \\
\hline & MCFHHHFHK & 612.27 & 1222.53 & 67 & 56 & 44 & 0 & 0 \\
\hline \multirow{10}{*}{$\underset{\mathrm{KCl}}{200 \mathrm{mM}}$} & DFPGAK & 317.66 & 633.33 & 17 & 17 & 67 & 17 & 17 \\
\hline & NDGPSR & 323.15 & 644.29 & 0 & 17 & 33 & 0 & 0 \\
\hline & AGFPLGK & 345.20 & 688.41 & 14 & 14 & 86 & 29 & 70 \\
\hline & AMQQDK & 360.66 & 719.32 & 0 & 17 & 33 & 17 & 17 \\
\hline & NLEGYR & 376.19 & 750.38 & 17 & 17 & 50 & 17 & 65 \\
\hline & YETLNR & 398.20 & 794.41 & 17 & 17 & 33 & 17 & 65 \\
\hline & MPPKSTR & 408.72 & 815.43 & 0 & 29 & 43 & 0 & 0 \\
\hline & TAGASLVAR & 423.25 & 844.49 & 0 & 11 & 67 & 56 & 109 \\
\hline & SSPATGGSLR & 466.74 & 931.49 & 0 & 10 & 50 & 20 & 49 \\
\hline & NANSLAGPQR & 514.27 & 1026.55 & 0 & 10 & 50 & 30 & 59 \\
\hline
\end{tabular}

a Molecular mass was calculated from the $m / z$ value determined by liquid chromatography-tandem mass spectrometry. ${ }^{b}$ Percentages of aromatic, basic, hydrophobic, and aliphatic residues as well as aliphatic index were computed by using Peptides Package in R. Aliphatic indices of reference peptides WAFAPA and MYPGLA as predicted by Peptides Package in R were 50 and 82 , respectively. 
Amino acid composition is a key factor influencing the antioxidant activity of peptides [5]. Hydrophobic residues made up 33-86\% of the compositions of the 29 CS peptides (Table 1). The presence of hydrophobic residue-containing peptides may account for the lipid peroxidation inhibitory effect of T1H [4], as well as that of $<3 \mathrm{kDa}$ UF (Figure 1E) and GF-III (Figure 2E,F), the peptide fractions which the 29 peptides were purified from. Hydrophobic residues may enhance the interaction of antioxidant peptides with lipid-soluble free radicals, thus attenuating the progression of lipid peroxidation [5]. Lipid oxidation is one of the major contributors to the deterioration of food quality during food processing and storage [5]. Thus, these CS peptides, as well the CS hydrolysate and partially purified fractions containing them, may be useful in the preservation of lipid-rich foods. On the other hand, it has been reported that peptides with C-terminal Lys could act as potent $\mathrm{H}_{2} \mathrm{O}_{2}$ scavengers [41]. Thus, MAPRTPRK and THAVKGVVHK in the $0 \mathrm{mM} \mathrm{KCl}$ fraction, FMFFVYK and MCFHHHFHK in the $20 \mathrm{mM} \mathrm{KCl}$ fraction, as well as DFPGAK, AGFPLGK, and AMQQDK in the $200 \mathrm{mM} \mathrm{KCl}$ fraction may have contributed to the $\mathrm{H}_{2} \mathrm{O}_{2}$ scavenging activity of the three SPE fractions.

The $0 \mathrm{mM} \mathrm{KCl}$ fraction had the highest proportion of peptides containing aromatic residues (9 peptides), followed by the $200 \mathrm{mM} \mathrm{KCl}$ (4 peptides) and the $20 \mathrm{mM} \mathrm{KCl}$ fractions (3 peptides). Aromatic residues may promote the antioxidant activity of peptides by donating protons to the electron-deficient radicals [36]. Notably, the $0 \mathrm{mM} \mathrm{KCl}$ fraction had the highest number of basic residue-containing peptides and the highest percentage of basic residues in peptides (Table 1). Thus, the strongest $\mathrm{ABTS}^{\bullet+}$ scavenging activity of the $0 \mathrm{mM} \mathrm{KCl}$ fraction may be attributed to its richness in peptides comprising aromatic and basic amino acids. Our result agrees with the finding that abundance in basic amino acids may account for the strong ABTS ${ }^{\bullet+}$ scavenging activity of a Chinese chestnut peptide fraction [37].

As revealed by the AnOxPePred analysis, 10 CS peptides (MCFHHHFHK, NLEGYR, AGFPLGK, FMFFVYK, NMVPGR, PVVWAAKR, DFPGAK, FSCPLVMKGPNGLR, RHGSGR, and VHFNKGKKR) had comparable or higher free radical scavenger (FRS) scores relative to the four reference peptides VGPWQK, MYPGLA, FPLPSF and WAFAPA (Table 2). The four reference peptides were empirically proven as $\mathrm{ABTS}^{\bullet+}$ scavengers $[11,39,42]$. Our results are in accordance with the finding that His, Trp, Tyr, and Pro are common in free-radical-scavenging peptides [17]. In this study, the four amino acids account for $11-44 \%$ of the residues making up the 10 CS peptides and the four reference peptides (Table 2). Notably, His-containing peptides were only found in the $0 \mathrm{mM} \mathrm{KCl}$ (THAVKGVVHK and VHFNKGKKR) and $20 \mathrm{mM} \mathrm{KCl}$ (RHGSGR and MCFHHHFHK) fractions, but none in the $200 \mathrm{mM} \mathrm{KCl}$ fraction (Table 1). This is in keeping with our observation that the 0 and $20 \mathrm{mM} \mathrm{KCl}$ fractions had at least 4-fold greater $\mathrm{ABTS}^{\bullet+}$ scavenging activity than the $200 \mathrm{mM} \mathrm{KCl}$ (Figure 3B). Our results, therefore, support the role of His residues in imparting radical scavenging activity to peptides [36].

Table 2. Free radical scavenger (FRS) scores of corn silk peptides were identified from the three SPE fractions, in comparison with reference peptides.

\begin{tabular}{ccc}
\hline Peptides & SPE Fractions & FRS Scores \\
\hline MCFHHHFHK & $20 \mathrm{mM} \mathrm{KCl}$ & 0.68068 \\
VGPWQK * $^{*}$ MYPGLA $^{*}$ & - & 0.52254 \\
NLEGYR & - & 0.49386 \\
AGFPLGK & $200 \mathrm{mM} \mathrm{KCl}$ & 0.48158 \\
FMFFVYK & $200 \mathrm{mM} \mathrm{KCl}$ & 0.44866 \\
NMVPGR & $20 \mathrm{mM} \mathrm{KCl}$ & 0.44397 \\
PVVWAAKR & $20 \mathrm{mM} \mathrm{KCl}$ & 0.44319 \\
\hline
\end{tabular}


Table 2. Cont.

\begin{tabular}{ccc}
\hline Peptides & SPE Fractions & FRS Scores \\
\hline DFPGAK & $200 \mathrm{mM} \mathrm{KCl}$ & 0.43574 \\
FPLPSF * & - & 0.43352 \\
FSCPLVMKGPNGLR & $0 \mathrm{mM} \mathrm{KCl}$ & 0.41864 \\
WAFAPA * & - & 0.41519 \\
RHGSGR & $20 \mathrm{mM} \mathrm{KCl}$ & 0.41088 \\
VHFNKGKKR & $0 \mathrm{mM} \mathrm{KCl}$ & 0.41055 \\
NANSLAGPQR & $200 \mathrm{mM} \mathrm{KCl}$ & 0.40415 \\
QVASGPLQR & $0 \mathrm{mM} \mathrm{KCl}$ & 0.40213 \\
MAPRTPRK & $0 \mathrm{mM} \mathrm{KCl}$ & 0.39973 \\
NDGPSR & $200 \mathrm{mM} \mathrm{KCl}$ & 0.38760 \\
KRYFKR & $0 \mathrm{mM} \mathrm{KCl}$ & 0.38352 \\
YETLNR & $200 \mathrm{mM} \mathrm{KCl}$ & 0.37938 \\
FQLKPVFR & $0 \mathrm{mM} \mathrm{KCl}$ & 0.37599 \\
ARVPQQSYR & $0 \mathrm{mM} \mathrm{KCl}$ & 0.37580 \\
YTWKFKGR & $0 \mathrm{mM} \mathrm{KCl}$ & 0.36769 \\
AMQQDK & $200 \mathrm{mM} \mathrm{KCl}$ & 0.36324 \\
SSPATGGSLR & $200 \mathrm{mM} \mathrm{KCl}$ & 0.35382 \\
THAVKGVVHK & $0 \mathrm{mM} \mathrm{KCl}$ & 0.35200 \\
MPPKSTR & $200 \mathrm{mM} \mathrm{KCl}$ & 0.33529 \\
LKKGSPLKR & $0 \mathrm{mM} \mathrm{KCl}$ & 0.32957 \\
PRVRVAGR & $0 \mathrm{mM} \mathrm{KCl}$ & 0.32698 \\
KVPLAVFSR & $0 \mathrm{mM} \mathrm{KCl}$ & 0.32525 \\
TAGASLVAR & $200 \mathrm{mM} \mathrm{KCl}$ & 0.32285 \\
TAPLSSKALKR & $0 \mathrm{mM} \mathrm{KCl}$ & 0.29320 \\
NKVVKLMR & $0 \mathrm{mM} \mathrm{KCl}$ & 0.27437 \\
\hline *Indicates & &
\end{tabular}

${ }^{*}$ Indicates reference peptides.

\subsection{Molecular Docking between CS Peptides and ABTS ${ }^{\bullet+}$}

Docking simulation was performed to clarify the interactions between $\mathrm{ABTS}^{\bullet+}$ and the 10 CS peptides with the best FRS scores. All seven peptides originating from the 0 and $20 \mathrm{mM} \mathrm{KCl}$ fractions had higher binding affinities towards $\mathrm{ABTS}^{\bullet+}$ than the two peptides (AGFPLGK and DFPGAK) from the $200 \mathrm{mM} \mathrm{KCl}$ fraction (Table 3). Five of the seven peptides (from 0 and $20 \mathrm{mM} \mathrm{KCl}$ fractions) were also stronger than NLEGYR (from $200 \mathrm{mM} \mathrm{KCl}$ fraction) in binding to $\mathrm{ABTS}^{\bullet+}$. The overall trend is in accordance with the relative levels of in vitro $\mathrm{ABTS}^{\bullet+}$ scavenging activity of the three SPE fractions (Figure 3B). Notably, the binding affinities of all seven peptides from the 0 and $20 \mathrm{mM} \mathrm{KCl}$ fractions were more negative than that of reference peptides MYPGLA. The binding energy of three peptides MCFHHHFHK, VHFNKGKKR, and PVVWAAKR was up to $21 \%$ more negative than all four reference peptides (Table 3). Taken together, the seven peptides originating from the 0 and $20 \mathrm{mM} \mathrm{KCl}$ fractions could bind to $\mathrm{ABTS}^{\bullet+}$ similarly or more stably than could the four reference peptides. Peptides that bind stably to free radicals can neutralize them. For instance, FPLPSF that was predicted to bind to ABTS ${ }^{\bullet+}$ has been experimentally demonstrated to quench $\mathrm{ABTS}^{\bullet+}$ in vitro [42]. Furthermore, our prediction of WAFAPA binding to $\mathrm{ABTS}^{\bullet+}$ more stably than could MYPGLA (Table 3 ) is also consistent with their relative in vitro antioxidant activity [11]. Altogether, our results suggest that the stronger $\mathrm{ABTS}^{\bullet+}$ scavenging activities of the 0 and $20 \mathrm{mM} \mathrm{KCl}$ fractions, relative to that of the $200 \mathrm{mM} \mathrm{KCl}$ fraction, could be accounted for, at least in part, by the affinity of their seven peptides to $\mathrm{ABTS}^{\bullet+}$. 
Table 3. Binding affinities and types of interactions between 10 corn silk peptides and ABTS ${ }^{\bullet+}$, in comparison with four reference peptides.

\begin{tabular}{ccccc}
\hline Peptides & SPE Fractions & $\begin{array}{c}\text { Binding Affinity } \\
\text { (kcal/mol) }\end{array}$ & \multicolumn{2}{c}{ Peptide Residues Interacting with ABTS •+ a } \\
\cline { 3 - 4 } & & -4.8 & Hydrogen Bond & Hydrophobic Interaction \\
\hline MCFHHHFHK & $20 \mathrm{mM} \mathrm{KCl}$ & -4.7 & - & Phe3, His6, Phe7 \\
VHFNKGKKR & $0 \mathrm{mM} \mathrm{KCl}$ & -4.7 & Lys7, Arg9 & Val1, His2, Gly6, Lys7, Arg9 \\
PVVWAAKR & $0 \mathrm{mM} \mathrm{KCl}$ & -4.4 & Arg8 (2) & Val2, Trp4, Ala5, Ala6, Arg8 \\
FMFFVYK & $20 \mathrm{mM} \mathrm{KCl}$ & Lys7 & Phe1, Phe3, Phe4, Lys7 \\
FSCPLVMKGPNGLR & $0 \mathrm{mM} \mathrm{KCl}$ & -4.2 & Arg14 (2) & Leu5, Lys8, Gly9, Pro10, Gly12, \\
NMVPGR & $20 \mathrm{mM} \mathrm{KCl}$ & -4.1 & Arg14 & Asn1, Pro4, Gly5, Arg6 \\
NLEGYR & $200 \mathrm{mM} \mathrm{KCl}$ & -4.1 & - & Tyr5, Arg6 \\
RHGSGR & $20 \mathrm{mM} \mathrm{KCl}$ & -3.9 & Arg1, Arg6 & Arg1, Gly5, Arg6 \\
AGFPLGK & $200 \mathrm{mM} \mathrm{KCl}$ & -3.7 & - & Phe3, Pro4, Leu5 \\
DFPGAK & $200 \mathrm{mM} \mathrm{KCl}$ & -3.6 & Pro3, Gly4, Lys6 \\
FPLPSF * & - & -4.6 & Phe1, Ser5 & Phe1, Pro2, Leu3, Pro4, Ser5 \\
WAFAPA * & - & -4.3 & - & Trp1, Ala4, Pro5 \\
VGPWQK * & - & -3.9 & Pro3, Trp4, Lys6 \\
MYPGLA * & - & -3.8 & Pro3 & Peu5, Ala6 \\
\hline
\end{tabular}

${ }^{*}$ Indicates reference peptides. ${ }^{a}$ Number in brackets indicates the number of interactions.

Our LigPlot+ analysis indicates significant participation of aromatic residues in CS peptide-ABTS ${ }^{\bullet+}$ interactions (Table 3). For instance, aromatic residues in $67 \%$ of the aromatic residue-containing peptides could bind to $\mathrm{ABTS}^{\bullet+}$ through hydrophobic interactions. Aromatic residue-ABTS ${ }^{\bullet+}$ interactions made up $14-100 \%$ of the total number of interactions between individual aromatic residue-containing peptides and ABTS ${ }^{\bullet+}$. Remarkably, all interactions formed between the best-binding-affinity MCFHHHFHK and ABTS ${ }^{\bullet+}$ were contributed by the aromatic residues Phe and His (Table 3). Four CS peptides, namely VHFNKGKKR, PVVWAAKR, FSCPLVMKGPNGLR, and NMVPGR, were predicted to have the highest number of interactions with $\mathrm{ABTS}^{\bullet+}$. Notwithstanding, the lack of participation of aromatic residues in the interactions between $\mathrm{ABTS}^{\bullet+}$ and the two peptides FSCPLVMKGPNGLR and NMVPGR apparently made their binding to ABTS ${ }^{\bullet+} 12-15 \%$ less stable relative to VHFNKGKKR and PVVWAAKR. Similarly, both WAFAPA and MYPGLA were predicted to form comparable numbers of interactions with ABTS ${ }^{\bullet+}$. However, the lack of participation of aromatic residues in MYPGLA-ABTS ${ }^{\bullet+}$ interaction may explain the reported weaker ABTS ${ }^{\bullet+}$ scavenging activity of MYPGLA when compared with WAFAPA [11]. Moreover, we also observed the significant participation of basic residues in peptide-ABTS ${ }^{\bullet+}$ interactions. Briefly, basic residues in $90 \%$ of basic residuecontaining CS peptides were involved in the interactions with ABTS ${ }^{\bullet+}$. Such interactions account for $33-80 \%$ of the total number of interactions between individual basic residuecontaining peptides and $\mathrm{ABTS}^{\bullet+}$. To further verify the role of the basic residues of peptides in binding to $\mathrm{ABTS}^{\bullet+}$, in silico alanine substitution was performed on those that were involved in $\mathrm{ABTS}^{\bullet+}$-peptide interactions, followed by docking of the alanine-substituted peptides to $\mathrm{ABTS}^{\bullet+}$. The binding affinities of all CS peptides, except FSCPLVMKGPNGLR, were diminished upon alanine mutagenesis of selected basic residues in the peptides (Tables 3 and 4). For instance, alanine substitution of His6 in MCFHHHFHK has resulted in a $15 \%$ reduction in the binding affinity of peptides towards ABTS ${ }^{\bullet+}$. Besides, a decline of $24 \%$ in binding affinity of NMVPGR towards ABTS ${ }^{\bullet+}$ was observed upon alanine substitution of Arg6. Our results suggest that the basic residues are likely to be critical in binding and stabilizing ABTS ${ }^{\bullet+}$. This observation further reinforces our finding that the $0 \mathrm{mM} \mathrm{KCl}$ fraction with the highest number of basic residue-containing peptides displayed the strongest $\mathrm{ABTS}^{\bullet+}$ scavenging activity (Table 1 and Figure 3B). Besides, Leu-ABTS ${ }^{\bullet+}$ interactions were observed in $67 \%$ of Leu-containing CS peptides (Table 3). Our observation agrees with a previous report of the participation of Leu in the binding between antioxidant peptides and $\mathrm{ABTS}^{\bullet+}[42]$. 
Table 4. Binding affinities of corn silk peptides toward ABTS ${ }^{\bullet+}$ upon alanine substitution of the basic residues that were involved in $\mathrm{ABTS}^{\bullet+}$-peptide interactions.

\begin{tabular}{cccc}
\hline Peptides $^{\text {a }}$ & Basic Residues & Mutant Peptides & $\begin{array}{c}\text { Binding Affinity } \\
\text { (kcal/mol) }\end{array}$ \\
\hline MCFHHHFHK & His6 & MCFHHAFHK & -4.1 \\
\hline \multirow{2}{*}{ VHFNKGKKR } & His2 & VAFNKGKKR & -4.8 \\
& Lys7 & VHFNKGAKR & -5.0 \\
\hline PVVWAAKR & Arg9 & VHFNKGKKA & -4.4 \\
\hline FMFFVYK & Arg8 & PVVWAAKA & -4.3 \\
\hline \multirow{2}{*}{ FSCPLVMKGPNGLR } & Lys7 & FMFFVYA & -4.3 \\
\hline NMVPGR & Lys8 & FSCPLVMAGPNGLR & -4.2 \\
\hline NLEGYR & Arg14 & FSCPLVMKGPNGLA & -4.7 \\
\hline \multirow{2}{*}{ RHGSGR } & Arg6 & NMVPGA & -3.1 \\
\hline DFPGAK & Arg6 & NLEGYA & -3.7 \\
\hline Arg1 & AHGSGR & -3.8 \\
\hline Peptides are arranged in the & Lys6 & RHGSGA & -4.2 \\
\hline
\end{tabular}

a Peptides are arranged in the same order as in Table 3.

\subsection{Molecular Docking of Peptides on Keap1}

Food-derived bioactive peptides, in addition to scavenging free radicals, can confer cellular protection by modulating the gene expression and activities of antioxidant and oxidant enzymes [5]. Given this, we conducted a docking-based screening experiment to unravel the potential of the 29 CS peptides identified in this study in interacting with cellular protein targets that can regulate the endogenous oxidant status: Keap1, MPO, and XO. Soy-derived DEQIPSHPPR was predicted in molecular docking study to interact stably with Keap1, in keeping with its demonstrated ability to disrupt Keap1-Nrf2 binding and increase Nrf2 levels in the nucleus [6]. Hence, DEQIPSHPPR was used as a reference peptide for comparison with CS peptides. Our docking results show that 13 of the 29 CS peptides could bind to Keap1 similarly or more stably than DEQIPSHPPR (Table S2). Further in silico screening for low toxicity and allergenicity as well as high cell-penetrating potential narrowed down the 13 CS peptides to five, namely NDGPSR, NLEGYR, NMVPGR, SSPATGGSLR, and NANSLAGPQR (Table 5). Screening based on these parameters allows the search for CS peptides that might be able to cross the cell membrane barrier and block the Keap1-Nrf2 interaction in cells with minimal or no harmful effects. Unlike the five CS peptides, the reference peptide DEQIPSHPPR may elicit allergy (Table 5), hence it is less desirable for the application of functional food ingredients.

The five aforementioned CS peptides successfully docked into Keap 1 and interacted with 3-6 of the seven key residues known to be involved in Keap1-Nrf2 interactions (Table 6). Our analysis on the reference peptide DEQIPSHPPR agrees with a previous report of its interaction with the key residues Arg380, Asn382, and Arg415 of Keap1 [6]. The participation of the three residues was also observed in the interactions between Keap1 and CS peptides (NANSLAGPQR and SSPATGGSLR) (Table 6). Besides, the binding of NLEGYR to Keap1 via hydrogen bond, hydrophobic interaction, and the salt bridge was also found in the DEQIPSHPPR-Keap1 interaction (Table 6). Thus, the five CS peptides apparently have comparable Keap1-binding properties as DEQIPSHPPR and could potentially activate the Keap1/Nrf2 pathway, triggering cellular antioxidant defense. 
Table 5. Toxicity, allergenicity, and cell-penetrating ability predicted for selected corn silk peptides that have the same or higher affinity to Kelch-like ECH-associated protein 1, myeloperoxidase, and xanthine oxidase, in comparison with reference peptides.

\begin{tabular}{clcc}
\hline Peptides & Toxicity & Allergenicity & CPP Prediction \\
\hline NDGPSR & Non-toxin & Probable non-allergen & CPP \\
NLEGYR & Non-toxin & Probable non-allergen & CPP \\
NMVPGR & Non-toxin & Probable non-allergen & CPP \\
SSPATGGSLR & Non-toxin & Probable non-allergen & CPP \\
NANSLAGPQR & Non-toxin & Probable non-allergen & CPP \\
KRYFKR & Non-toxin & Probable non-allergen & CPP \\
RHGSGR & Non-toxin & Probable non-allergen & CPP \\
YETLNR & Non-toxin & Probable non-allergen & Non-CPP \\
AGFPLGK & Non-toxin & Probable non-allergen & Non-CPP \\
KVPLAVFSR & Non-toxin & Probable non-allergen & Non-CPP \\
TAGASLVAR & Non-toxin & Probable allergen & Non-CPP \\
YTWKFKGR & Non-toxin & Probable allergen & CPP \\
AMQQDK & Non-toxin & Probable allergen & CPP \\
MPPKSTR & Non-toxin & Probable allergen & CPP \\
PVVWAAKR & Non-toxin & Probable allergen & CPP \\
DFPGAK & Non-toxin & Probable allergen & Non-CPP \\
FMFFVYK & Non-toxin & Probable allergen & Non-CPP \\
QVASGPLQR & Non-toxin & Probable allergen & Non-CPP \\
DEQIPSHPPR * & Non-toxin & Probable allergen & Non-CPP \\
DTETGVPT * & Non-toxin & Probable non-allergen & Non-CPP \\
VPY * & Non-toxin & Probable allergen & CPP \\
ACECD * & Non-toxin & Probable allergen & CPP \\
\hline
\end{tabular}

*Indicates reference peptides. CPP, cell-penetrating peptide.

Table 6. Binding affinities and types of interactions between Kelch-like ECH-associated protein 1 (Keap1) and five corn silk peptides predicted as non-toxic, non-allergenic and cell-penetrating peptides, in comparison with a reference peptide.

\begin{tabular}{|c|c|c|c|c|}
\hline \multirow{2}{*}{ Peptides } & \multirow{2}{*}{$\begin{array}{l}\text { Binding Affinity } \\
\text { (kcal/mol) }\end{array}$} & \multicolumn{2}{|c|}{ Interaction with Keap1 ${ }^{a}$} & \multirow[b]{2}{*}{ Salt Bridge } \\
\hline & & Hydrogen Bond & Hydrophobic Interaction & \\
\hline NLEGYR & -8.7 & $\begin{array}{c}\text { Arg415, Arg483, } \\
\text { Ser508, Gln530, Ser555 }\end{array}$ & $\begin{array}{l}\text { Tyr334, Ser363, Gly364, Leu365, Ala366, } \\
\text { Arg415, Ile416, Gly417, Gly462, Phe478, } \\
\text { Arg483, Ser508, Gly509, Ala510, Tyr525, } \\
\text { Gln530, Ser555, Ala556, Leu557, Tyr572, } \\
\text { Phe577, Ser602, Gly603, Val604 }\end{array}$ & Arg415 \\
\hline NANSLAGPQR & -8.2 & $\begin{array}{l}\text { Arg415 (3), Val418, } \\
\text { Val465, Arg483 }\end{array}$ & $\begin{array}{l}\text { Ser363, Gly364, Leu365, Arg380, Asn382, } \\
\text { Asn414, Arg415, Ile416, Gly417, Ile461, } \\
\text { Gly462, Val463, Val465, Phe478, Arg483, } \\
\text { Ser508, Gly509, Tyr525, Gln530, Ser555, } \\
\text { Ala556, Ile559, Phe577, Gly603 }\end{array}$ & - \\
\hline NMVPGR & -8.1 & $\begin{array}{c}\text { Ser363, Leu365, Asn382, } \\
\text { Ser602 }\end{array}$ & $\begin{array}{c}\text { Tyr334, Ser363, Gly364, Leu365, Ala366, } \\
\text { Asn382, Arg415, Ile416, Ile461, Gly462, } \\
\text { Ser508, Gly509, Ala510, Tyr525, Gln530, } \\
\text { Ser555, Ala556, Ser602 }\end{array}$ & - \\
\hline SSPATGGSLR & -8.1 & $\begin{array}{c}\text { Ser363, Arg380, } \\
\text { Asn414, Arg415, Ser431, } \\
\text { Ser602 }\end{array}$ & $\begin{array}{l}\text { Tyr334, Gly364, Leu365, Arg380, } \\
\text { Asn382, Asn414, Arg415, Ile416, Ser431, } \\
\text { Gly433, His436, Gly462, Phe478, Arg483, } \\
\text { Ser508, Gly509, Ala556, Ser602, Gly603 }\end{array}$ & - \\
\hline NDGPSR & -8.0 & Arg415 (2), Ala510 & $\begin{array}{l}\text { Tyr334, Gly364, Leu365, Arg415, Ile461, } \\
\text { Gly462, Phe478, Ser508, Gly509, Tyr525, } \\
\text { Ala556, Ser602, Gly603, Val604 }\end{array}$ & - \\
\hline
\end{tabular}


Table 6. Cont.

\begin{tabular}{|c|c|c|c|c|}
\hline \multirow{2}{*}{ Peptides } & \multirow{2}{*}{$\begin{array}{l}\text { Binding Affinity } \\
\text { (kcal/mol) }\end{array}$} & \multicolumn{2}{|c|}{ Interaction with Keap1 a } & \multirow[b]{2}{*}{ Salt Bridge } \\
\hline & & Hydrogen Bond & Hydrophobic Interaction & \\
\hline DEQIPSHPPR * & -8.0 & $\begin{array}{l}\text { Tyr334, Asn414, } \\
\text { Arg415 (4), Ser431, } \\
\text { Arg483 (3), Ser555 }\end{array}$ & $\begin{array}{l}\text { Tyr334, Ser363, Arg380, Asn382, Asn414, } \\
\text { Arg415, Ser431, Gly433, His436, Gly462, } \\
\text { Phe478, Arg483, Ser508, Gly509, Tyr525, } \\
\text { Ser555, Ala556, Tyr572, Phe577, Ser602 }\end{array}$ & $\operatorname{Arg} 483(2)$ \\
\hline
\end{tabular}

${ }^{*}$ Indicates reference peptide. a Number in brackets indicates the number of interactions. Residues in bold are key residues (Tyr334, Arg380, Arg415, Arg483, Tyr525, Tyr572, and Phe577) in the binding site of Keap1 for nuclear factor erythroid 2-related factor 2 [7].

\subsection{Molecular Docking of Peptides on MPO}

In this study, CS peptides were compared with the soy tripeptide VPY and false abalone-derived DTETGVPT in their affinity towards MPO. Oral administration of VPY was shown to induce a 4 -fold reduction in the MPO activity of mice [43]. Meanwhile, DTETGVPT is a potential inhibitor of MPO, as revealed by molecular docking simulation [44]. Our results revealed that 12 of the 29 CS peptides had up to $23 \%$ stronger affinity to MPO when compared with DTETGVPT, but were all weaker than VPY (Table S2). Five of the 12 potential MPO-binding CS peptides, namely NDGPSR, NLEGYR, NMVPGR, KRYFKR, and RHGSGR, were found to have low toxicity, low allergenicity, and cell-penetrating potential (Table 5). The five CS peptides would thus have an advantage over the reference peptide VPY (probable allergen) and DTETGVPT (non-cell-penetrating peptide) (Table 5) in the context of the application as food additives or functional food ingredients.

The interactions between the five CS peptides and MPO active site residues were highly similar to those between the reference peptides (VPY and DTETGVPT) and MPO (Table 7). With the exemption of NLEGYR, CS peptides and reference peptides were all forming only the hydrophobic interaction with the key residues in MPO active site. Likewise, similar to the reference peptides, each CS peptide could interact with 4-5 of the seven key residues in the active site of MPO. These key residues contributed to the stability of the interaction between 7-benzyl-1H-[1,2,3]triazolo[4,5-b]pyridin-5-amine, the bound inhibitor in the MPO crystal, and the active site of MPO [25]. As observed in the two reference peptides, all the five CS peptides could bind directly to the heme moiety of MPO (Table 7). Blockage of the heme pocket of MPO could preclude the access of substrates to the MPO active site, suppressing the enzyme's action-driving ROS production [45].

Table 7. Binding affinities and types of interactions between myeloperoxidase (MPO) and five corn silk peptides predicted as non-toxic, non-allergenic and cell-penetrating peptides, in comparison with two reference peptides.

\begin{tabular}{|c|c|c|c|c|}
\hline \multirow{2}{*}{ Peptides } & \multirow{2}{*}{$\begin{array}{l}\text { Binding Affinity } \\
\text { (kcal/mol) }\end{array}$} & \multicolumn{2}{|c|}{ Interaction with $\mathrm{MPO}^{\mathrm{a}}$} & \multirow[b]{2}{*}{ Salt Bridge } \\
\hline & & Hydrogen Bond & Hydrophobic Interaction & \\
\hline NMVPGR & -6.6 & - & $\begin{array}{l}\text { Phe99, Thr100, Glu102, Glu116, } \\
\text { Pro145, Phe147, Leu216, Pro220, } \\
\text { Arg239, Glu242, Phe366, Phe407, } \\
\text { Met411, Arg424, Hec606 }\end{array}$ & - \\
\hline NLEGYR & -6.5 & His95 & $\begin{array}{c}\text { His95, Phe99, Glu102, Glu116, Pro145, } \\
\text { Phe146, Phe147, Pro220, Thr238, } \\
\text { Arg239, Glu242, Phe407, Val410, } \\
\text { Met411, Leu420, Hec606 }\end{array}$ & - \\
\hline NDGPSR & -6.3 & Glu102 & $\begin{array}{l}\text { Phe99, Glu102, Glu116, Pro145, } \\
\text { Phe146, Phe147, Pro220, Thr238, } \\
\text { Arg239, Glu242, Phe366, Phe407, } \\
\text { Met411, Leu415, Leu420, Hec606 }\end{array}$ & - \\
\hline
\end{tabular}


Table 7. Cont.

\begin{tabular}{|c|c|c|c|c|}
\hline \multirow{2}{*}{ Peptides } & \multirow{2}{*}{$\begin{array}{l}\text { Binding Affinity } \\
\text { (kcal/mol) }\end{array}$} & \multicolumn{2}{|c|}{ Interaction with $\mathrm{MPO}^{\mathrm{a}}$} & \multirow[b]{2}{*}{ Salt Bridge } \\
\hline & & Hydrogen Bond & Hydrophobic Interaction & \\
\hline RHGSGR & -6.2 & Thr100, Thr238 & $\begin{array}{l}\text { Phe99, Thr100, Glu102, Pro145, } \\
\text { Phe146, Phe147, Leu216, Pro220, } \\
\text { Thr238, Arg239, Glu242, Phe366, } \\
\text { Phe407, Met411, Leu415, Hec606 }\end{array}$ & Glu102 (5) \\
\hline KRYFKR & -5.5 & Thr100, Thr238 & $\begin{array}{c}\text { His95, Phe99, Thr100, Glu102, Glu116, } \\
\text { Pro145, Phe147, Pro220, Thr238, } \\
\text { Arg239, Glu242, Phe366, Phe407, } \\
\text { Val410, Met411, Leu415, } \\
\text { Leu420, Hec606 }\end{array}$ & Glu102 (2) \\
\hline VPY * & -7.4 & - & $\begin{array}{c}\text { His95, Phe99, Thr100, Glu102, Pro220, } \\
\text { Thr238, Arg239, Glu242, } \\
\text { Phe366, Hec606 }\end{array}$ & - \\
\hline DTETGVPT * & -5.5 & Thr238 & $\begin{array}{l}\text { Phe99, Thr100, Glu102, Phe147, } \\
\text { Pro220, Thr238, Arg239, Glu242, } \\
\text { Phe366, Phe407, Met411, Leu415, } \\
\text { Leu420, Hec606 }\end{array}$ & - \\
\hline
\end{tabular}

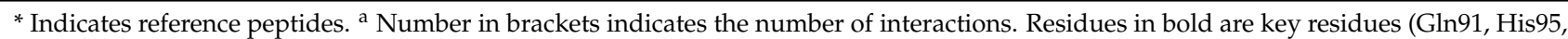
Phe99, Arg239, His336, Phe366, and Phe407) in the active site of MPO [25].

\subsection{Molecular Docking of Peptides on XO}

Only 14 of the 29 CS peptides were docked onto XO successfully, yielding negative values for binding affinity (Table S2). Docking of NDGPSR and DFPGAK onto XO involved the lowest binding energy, thus the strongest affinity, among the 14 peptides. Furthermore, NDGPSR and DFPGAK were predicted to bind equally stably to XO as was ACECD, the reference peptide. ACECD, an XO inhibitory peptide derived from Skipjack tuna hydrolysate, was reported to exert its inhibition by binding to the active site of XO [46]. In light of the predicted allergenicity and non-cell-penetrating potential of DFPGAK (Table 5), we proceeded to analyze the intermolecular interactions in only the NDGPSR-XO docked model.

As shown in Table 8, our LigPlot+ analysis revealed that NDGPSR could interact with catalytically critical residues (Glu802 and Arg880), substrate binding-residue (Phe914, Phe1009, and Thr1010), and the residues associated with the extended solventaccessible channel leading to the molybdenum active center (Leu873, Val1011, Phe1013, and Leu1014) [26]. Most of such interactions are hydrophobic in nature. The dominance of hydrophobic interactions was also observed in our ACECD-XO docked model (Table 8). Meanwhile, NDGPSR could form hydrophobic interaction with Glu1261, an amino acid around the active center of $\mathrm{XO}$, and contribute to the catalytic reaction of $\mathrm{XO}$ [46]. Moreover, as observed in ACECD, NDGPSR could also interact with Leu648 and Phe649 through hydrophobic interactions. The two residues are at the gate of the aforementioned solventaccessible channel [26]. Interactions with Leu648 and Phe649 were reported to enhance the potency of quercetin as an XO inhibitor [26]. Altogether, our results suggest that NDGPSR can potentially occupy the catalytic center of $\mathrm{XO}$, hindering the entry of $\mathrm{XO}$ substrates, thereby suppressing $\mathrm{XO}$ activity and $\mathrm{ROS}$ generation. In addition to their protective role in cells, antioxidant peptides with $\mathrm{XO}$ inhibitory activity are useful in reducing milk-fat oxidation in the dairy industry [9]. Thus, NDGPSR may also be developed into a potent antioxidant for the formulation of dairy products and other oxidation-prone foods.

Our in silico analysis revealed three multifunctional peptides that are also nontoxic, non-allergenic, and have cell-penetrating potential, namely NDGPSR, NLEGYR, and NMVPGR. Among the three, NDGPSR could be a potential inhibitor of Keap1-Nrf2 interaction, MPO, and XO. Models of NDGPSR docked to the three protein targets are shown in Figure 4. Moreover, NLEGYR and NMVPGR could be potential dual-function inhibitors of Keap1-Nrf2 interaction and MPO (Table S2). Antioxidant peptides possessing 
multiple functionalities likely have greater versatility and commercial value when compared to other antioxidant peptides [36]. In this context, the three multifunctional peptides, with their safety and cell-penetrating properties, are desirable candidates for the future development of functional food ingredients and/or health supplements.

Table 8. Binding affinity and types of interactions between xanthine oxidase $(X O)$ and corn silk peptide NDGPSR, which was predicted to be a non-toxic, non-allergenic, and cell-penetrating peptide, in comparison with a reference peptide.

\begin{tabular}{|c|c|c|c|c|}
\hline \multirow{2}{*}{ Peptides } & \multirow{2}{*}{$\begin{array}{l}\text { Binding Affinity } \\
\text { (kcal/mol) }\end{array}$} & \multicolumn{2}{|c|}{ Interaction with $\mathrm{XO}^{\mathrm{a}}$} & \multirow[b]{2}{*}{ Salt Bridge } \\
\hline & & Hydrogen Bond & Hydrophobic Interaction & \\
\hline NDGPSR & -5.2 & $\begin{array}{c}\text { Ser876, Thr1010, } \\
\text { Val1011 }\end{array}$ & $\begin{array}{c}\text { Leu648, Phe649, Gly799, Glu802, } \\
\text { Leu873, His875, Ser876, Arg880, Phe914, } \\
\text { Phe1009, Thr1010, Val1011, Pro1012, } \\
\text { Phe1013, Leu1014, Ala1078, } \\
\text { Ala1079, Glu1261 }\end{array}$ & $\begin{array}{c}\text { His875, } \\
\text { Glu1261 (2) }\end{array}$ \\
\hline $\mathrm{ACECD}$ * & -5.2 & His875, Ser876 & $\begin{array}{c}\text { Leu648, Phe649, Glu802, Leu873, } \\
\text { His875, Ser876, Glu879, Phe914, } \\
\text { Phe1009, Thr1010, Val1011, Pro1012, } \\
\text { Phe1013, Leu1014 }\end{array}$ & - \\
\hline
\end{tabular}

* Indicates reference peptide. a Number in brackets indicates the number of interactions. Residues in bold are key residues (Glu802, Leu873, Arg880, Phe914, Phe1009, Thr1010, Val1011, Phe1013, and Leu1014) in the active site of XO [26].

(A) Keap1-NDGPSR

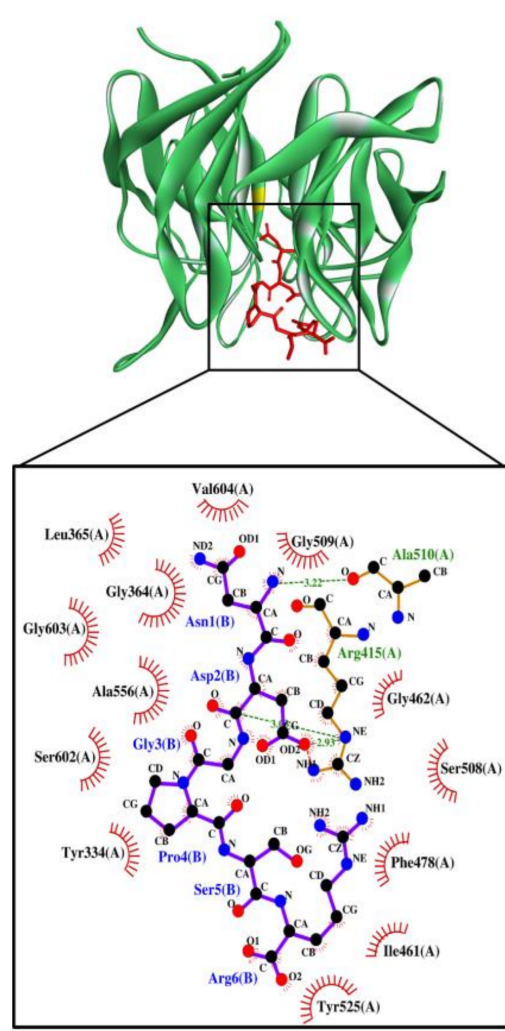

(B) MPO-NDGPSR

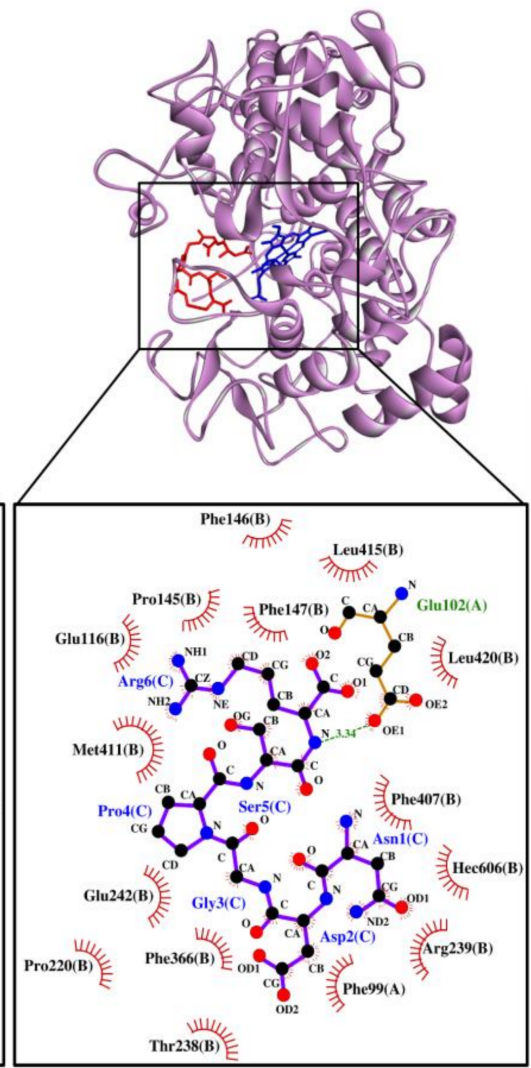

(C) XO-NDGPSR

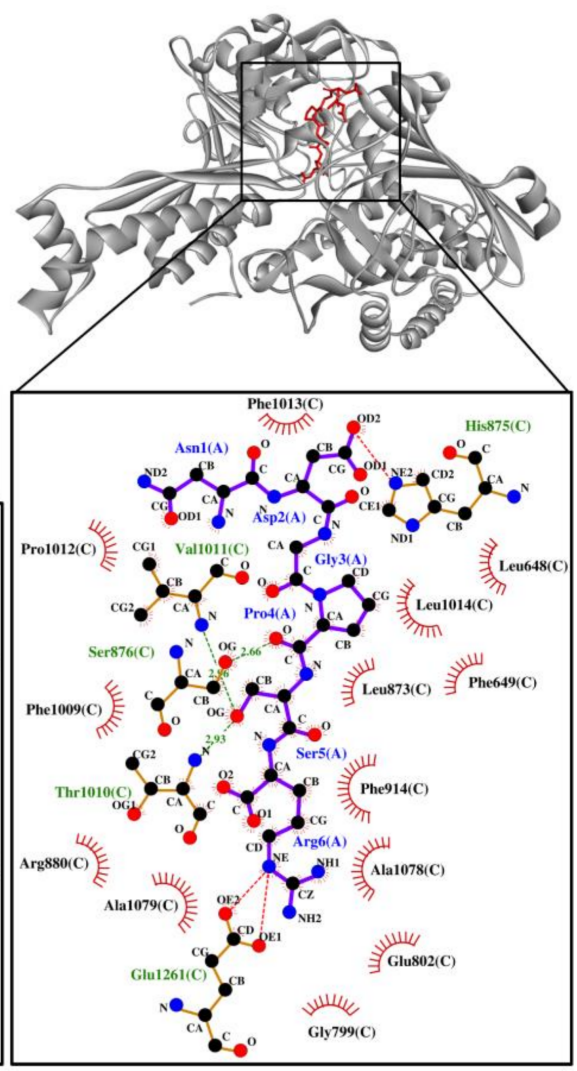

Figure 4. The docked models of NDGPSR interacting with (A) Keap1, (B) MPO, and (C) XO in 3D (top) and 2D (bottom) diagrams. In the 3D diagrams, NDGPSR is displayed in red; the heme moiety of MPO in (B) is displayed in blue. In the 2D diagrams, bonds of proteins are in orange, whereas those of peptides are in purple. Hydrophobic interactions, hydrogen bonds, and salt bridges are represented in red spoked arcs, green dashed lines, and red dashed lines, respectively. 


\section{Conclusions}

In this study, 29 potential antioxidant peptides were purified and identified, for the first time, from a CS hydrolysate. The prevalence of aromatic and basic residues, in addition to binding affinity to $\mathrm{ABTS}^{\bullet+}$, as revealed by molecular docking simulation, may account for the antioxidant activities of the peptides. Our in silico study also unraveled the potential of the peptides as inhibitors of Keap1-Nrf2 interaction, MPO and XO. NDGPSR stood out among the 29 peptides for its concurrent affinities towards the three protein targets, besides being predicted as non-toxic, non-allergenic, and having cell-penetrating potential. Taken together, our findings highlight the potential of CS as a source of antioxidant peptides with desirable properties for future applications in functional food and drug discovery. Future investigations by using in vitro and in vivo models are warranted for more in-depth exploration of CS-derived antioxidant peptides highlighted in this study.

Supplementary Materials: The following are available online at https:/ /www.mdpi.com/article/10 .3390 /antiox10111822/s1, Table S1: Coordinates of box center and box size for molecular docking with different targets by using Webina 1.0.2, and the root mean square deviation (RMSD) values obtained, Table S2: Binding affinities of 29 corn silk peptides docked onto Keap1, MPO and XO.

Author Contributions: Conceptualization and methodology, H.C., S.-A.T., F.A.M., F.-C.W. and T.-T.C.; software and supervision, F.-C.W. and T.-T.C.; formal analysis, investigation, data curation, and project administration, J.-H.O. and J.-A.K.; writing—original draft preparation, J.-H.O., F.-C.W. and T.-T.C.; writing-review and editing, J.-A.K., H.C., S.-A.T., F.A.M. and F.-C.W. All authors have read and agreed to the published version of the manuscript.

Funding: This research received no external funding.

Institutional Review Board Statement: Not applicable.

Informed Consent Statement: Not applicable.

Data Availability Statement: Data is contained within the article and supplementary material.

Acknowledgments: We thank Clara Chia-Ci Wong for her assistance in the molecular docking analysis of $\mathrm{ABTS}^{\bullet+}$-peptide interactions.

Conflicts of Interest: The authors declare no conflict of interest.

\section{References}

1. Hasanudin, K.; Hashim, P.; Mustafa, S. Corn silk (Stigma maydis) in healthcare: A phytochemical and pharmacological review. Molecules 2012, 17, 9697-9715. [CrossRef] [PubMed]

2. Li, C.-C.; Lee, Y.-C.; Lo, H.-Y.; Huang, Y.-W.; Hsiang, C.-Y.; Ho, T.-Y. Antihypertensive effects of corn silk extract and its novel bioactive constituent in spontaneously hypertensive rats: The involvement of angiotensin-converting enzyme inhibition. Molecules 2019, 24, 1886. [CrossRef]

3. Ho, T.-Y.; Li, C.-C.; Lo, H.-Y.; Chen, F.-Y.; Hsiang, C.-Y. Corn silk extract and its bioactive peptide ameliorated lipopolysaccharideinduced inflammation in mice via the nuclear factor-кB signaling pathway. J. Agric. Food Chem. 2017, 65, 759-768. [CrossRef]

4. Chai, T.-T.; Ang, S.-Y.; Goh, K.; Lee, Y.-H.; Ngoo, J.-M.; Teh, L.-K.; Wong, F.-C. Trypsin-hydrolyzed corn silk proteins: Antioxidant activities, in vitro gastrointestinal and thermal stability, and hematoprotective effects. eFood 2020, 1, 156-164. [CrossRef]

5. Wong, F.-C.; Xiao, J.; Wang, S.; Ee, K.-Y.; Chai, T.-T. Advances on the antioxidant peptides from edible plant sources. Trends Food Sci. Technol. 2020, 99, 44-57. [CrossRef]

6. Tonolo, F.; Moretto, L.; Grinzato, A.; Fiorese, F.; Folda, A.; Scalcon, V.; Ferro, S.; Arrigoni, G.; Bellamio, M.; Feller, E.; et al. Fermented soy-derived bioactive peptides selected by a molecular docking approach show antioxidant properties involving the Keap1/Nrf2 pathway. Antioxidants 2020, 9, 1306. [CrossRef]

7. Winkel, A.F.; Engel, C.K.; Margerie, D.; Kannt, A.; Szillat, H.; Glombik, H.; Kallus, C.; Ruf, S.; Güssregen, S.; Riedel, J.; et al. Characterization of RA839, a noncovalent small molecule binder to Keap1 and selective activator of Nrf2 signaling. J. Biol. Chem. 2015, 290, 28446-28455. [CrossRef]

8. Deng, Z.; Cui, C.; Wang, Y.; Ni, J.; Zheng, L.; Wei, H.-K.; Peng, J. FSGHF3 and peptides, prepared from fish skin gelatin, exert a protective effect on DSS-induced colitis via the Nrf2 pathway. Food Funct. 2020, 11, 414-423. [CrossRef] [PubMed]

9. Thaha, A.; Wang, B.-S.; Chang, Y.-W.; Hsia, S.-M.; Huang, T.-C.; Shiau, C.-Y.; Hwang, D.-F.; Chen, T.-Y. Food-derived bioactive peptides with antioxidative capacity, xanthine oxidase and tyrosinase inhibitory activity. Processes 2021, 9, 747. [CrossRef]

10. Nielsen, P.M.; Petersen, D.; Dambmann, C. Improved method for determining food protein degree of hydrolysis. J. Food Sci. 2001, 66, 642-646. [CrossRef] 
11. Wong, F.-C.; Xiao, J.; Ong, M.G.-L.; Pang, M.-J.; Wong, S.-J.; Teh, L.-K.; Chai, T.-T. Identification and characterization of antioxidant peptides from hydrolysate of blue-spotted stingray and their stability against thermal, $\mathrm{pH}$ and simulated gastrointestinal digestion treatments. Food Chem. 2019, 271, 614-622. [CrossRef] [PubMed]

12. Bradford, M.M. A rapid and sensitive method for the quantitation of microgram quantities of protein utilizing the principle of protein-dye binding. Anal. Biochem. 1976, 72, 248-254. [CrossRef]

13. Chai, T.-T.; Kwek, M.-T.; Ong, H.-C.; Wong, F.-C. Water fraction of edible medicinal fern Stenochlaena palustris is a potent $\alpha$-glucosidase inhibitor with concurrent antioxidant activity. Food Chem. 2015, 186, 26-31. [CrossRef]

14. Lamiable, A.; Thévenet, P.; Rey, J.; Vavrusa, M.; Derreumaux, P.; Tufféry, P. PEP-FOLD3: Faster denovo structure prediction for linear peptides in solution and in complex. Nucleic Acids Res. 2016, 44, W449-W454. [CrossRef]

15. Thévenet, P.; Shen, Y.; Maupetit, J.; Guyon, F.; Derreumaux, P.; Tufféry, P. PEP-FOLD: An updated de novo structure prediction server for both linear and disulfide bonded cyclic peptides. Nucleic Acids Res. 2012, 40, W288-W293. [CrossRef] [PubMed]

16. Shen, Y.; Maupetit, J.; Derreumaux, P.; Tufféry, P. Improved PEP-FOLD approach for peptide and miniprotein structure prediction. J. Chem. Theory Comput. 2014, 10, 4745-4758. [CrossRef] [PubMed]

17. Olsen, T.H.; Yesiltas, B.; Marin, F.I.; Pertseva, M.; García-Moreno, P.J.; Gregersen, S.; Overgaard, M.T.; Jacobsen, C.; Lund, O.; Hansen, E.B.; et al. AnOxPePred: Using deep learning for the prediction of antioxidative properties of peptides. Sci. Rep. 2020, 10, 21471. [CrossRef]

18. Kim, S.; Thiessen, P.A.; Bolton, E.E.; Chen, J.; Fu, G.; Gindulyte, A.; Han, L.; He, J.; He, S.; Shoemaker, B.A.; et al. PubChem substance and compound databases. Nucleic Acids Res. 2016, 44, D1202-D1213. [CrossRef] [PubMed]

19. Schüttelkopf, A.W.; van Aalten, D.M.F. PRODRG: A tool for high-throughput crystallography of protein-ligand complexes. Acta Crystallogr. D Biol. Crystallogr. 2004, 60, 1355-1363. [CrossRef]

20. Morris, G.M.; Huey, R.; Lindstrom, W.; Sanner, M.F.; Belew, R.K.; Goodsell, D.S.; Olson, A.J. AutoDock4 and AutoDockTools4: Automated docking with selective receptor flexibility. J. Comput. Chem. 2009, 30, 2785-2791. [CrossRef]

21. Sanner, M.F. Python: A programming language for software integration and development. J. Mol. Graph. Model. 1999, 17, 57-61. [PubMed]

22. Kochnev, Y.; Hellemann, E.; Cassidy, K.C.; Durrant, J.D. Webina: An open-source library and web app that runs AutoDock Vina entirely in the web browser. Bioinformatics 2020, 36, 4513-4515. [CrossRef] [PubMed]

23. Wallace, A.C.; Laskowski, R.A.; Thornton, J.M. LIGPLOT: A program to generate schematic diagrams of protein-ligand interactions. Protein Eng. 1995, 8, 127-134. [CrossRef] [PubMed]

24. Laskowski, R.A.; Swindells, M.B. LigPlot+: Multiple ligand-protein interaction diagrams for drug discovery. J. Chem. Inf. Model. 2011, 51, 2778-2786. [CrossRef]

25. Shaw, S.A.; Vokits, B.P.; Dilger, A.K.; Viet, A.; Clark, C.G.; Abell, L.M.; Locke, G.A.; Duke, G.; Kopcho, L.M.; Dongre, A.; et al. Discovery and structure activity relationships of 7-benzyl triazolopyridines as stable, selective, and reversible inhibitors of myeloperoxidase. Bioorg. Med. Chem. 2020, 28, 115723. [CrossRef]

26. Cao, H.; Pauff, J.M.; Hille, R. X-ray crystal structure of a xanthine oxidase complex with the flavonoid inhibitor quercetin. J. Nat. Prod. 2014, 77, 1693-1699. [CrossRef]

27. Berman, H.M.; Westbrook, J.; Feng, Z.; Gilliland, G.; Bhat, T.N.; Weissig, H.; Shindyalov, I.N.; Bourne, P.E. The Protein Data Bank. Nucleic Acids Res. 2000, 28, 235-242. [CrossRef]

28. Burley, S.K.; Bhikadiya, C.; Bi, C.; Bittrich, S.; Chen, L.; Crichlow, G.V.; Christie, C.H.; Dalenberg, K.; Di Costanzo, L.; Duarte, J.M.; et al. RCSB Protein Data Bank: Powerful new tools for exploring 3D structures of biological macromolecules for basic and applied research and education in fundamental biology, biomedicine, biotechnology, bioengineering and energy sciences. Nucleic Acids Res. 2021, 49, D437-D451. [CrossRef] [PubMed]

29. Wong, F.-C.; Ong, J.-H.; Chai, T.-T. Identification of putative cell-entry-inhibitory peptides against SARS-CoV-2 from edible insects: An in silico study. eFood 2020, 1, 357-368. [CrossRef]

30. Osorio, D.; Rondón-Villarreal, P.; Torres, R. Peptides: A package for data mining of antimicrobial peptides. $R$ J 2015, 7, 4-14. [CrossRef]

31. Gupta, S.; Kapoor, P.; Chaudhary, K.; Gautam, A.; Kumar, R.; Raghava, G.P.S. In silico approach for predicting toxicity of peptides and proteins. PLOS ONE 2013, 8, e73957.

32. Dimitrov, I.; Bangov, I.; Flower, D.R.; Doytchinova, I. AllerTOP v.2-a server for in silico prediction of allergens. J. Mol. Model. 2014, 20, 2278. [CrossRef]

33. de Oliveira, E.C.L.; Santana, K.; Josino, L.; Lima, E.; Lima, A.H.; de Souza Sales Júnior, C. Predicting cell-penetrating peptides using machine learning algorithms and navigating in their chemical space. Sci. Rep. 2021, 11, 7628. [CrossRef] [PubMed]

34. Sharmila, M.D.; Chai, T.-T.; Wong, F.-C. Antioxidant and protein protection potentials of fennel seed-derived protein hydrolysates and peptides. Mod. Food Sci. Technol. 2019, 35, 22-29.

35. Hu, R.; Dunmire, K.M.; Truelock, C.N.; Paulk, C.B.; Aldrich, G.; Li, Y. Antioxidant performances of corn gluten meal and DDGS protein hydrolysates in food, pet food, and feed systems. J. Sci. Food Agric. 2020, 2, 100030. [CrossRef]

36. Chai, T.-T.; Law, Y.-C.; Wong, F.-C.; Kim, S.-K. Enzyme-assisted discovery of antioxidant peptides from edible marine invertebrates: A review. Mar. Drugs 2017, 15, 42. [CrossRef]

37. Feng, Y.-X.; Ruan, G.-R.; Jin, F.; Xu, J.; Wang, F.-J. Purification, identification, and synthesis of five novel antioxidant peptides from Chinese chestnut (Castanea mollissima Blume) protein hydrolysates. LWT 2018, 92, 40-46. [CrossRef] 
38. Wang, X.; Zheng, X.; Kopparapu, N.; Cong, W.; Deng, Y.; Sun, X.; Liu, X. Purification and evaluation of a novel antioxidant peptide from corn protein hydrolysate. Process Biochem. 2014, 49, 1562-1569. [CrossRef]

39. Chai, T.-T.; Xiao, J.; Mohana Dass, S.; Teoh, J.-Y.; Ee, K.-Y.; Ng, W.-J.; Wong, F.-C. Identification of antioxidant peptides derived from tropical jackfruit seed and investigation of the stability profiles. Food Chem. 2021, 340, 127876. [CrossRef]

40. He, R.; Ju, X.; Yuan, J.; Wang, L.; Girgih, A.T.; Aluko, R.E. Antioxidant activities of rapeseed peptides produced by solid state fermentation. Food Res. Int. 2012, 49, 432-438. [CrossRef]

41. Mishra, M.; Nagarajan, K. Assessment of antioxidant influence of short series peptides using hydrogen peroxide scavenging assay and superoxide radical scavenging activity. World J. Pharm. Pharm. Sci. 2018, 7, 1064-1070.

42. Chen, T.; Chen, Z.; Wang, H.; Chen, X.; Yang, J.; Han, A.; Lin, D.-H.; Hong, J. Underlying action mechanism of a novel antioxidant peptide derived from Allium tuberosum Rottler protein hydrolysates and its protective effects on hydrogen peroxide induced cell injury. J. Funct. Foods 2018, 40, 606-613. [CrossRef]

43. Kovacs-Nolan, J.; Zhang, H.; Ibuki, M.; Nakamori, T.; Yoshiura, K.; Turner, P.V.; Matsui, T.; Mine, Y. The PepT1-transportable soy tripeptide VPY reduces intestinal inflammation. Biochim. Biophys. Acta 2012, 1820, 1753-1763. [CrossRef]

44. He, S.; Zhang, Y.; Sun, H.; Du, M.; Qiu, J.; Tang, M.; Sun, X.; Zhu, B. Antioxidative peptides from proteolytic hydrolysates of false abalone (Volutharpa ampullacea perryi): Characterization, identification, and molecular docking. Mar. Drugs 2019, 17, 116. [CrossRef] [PubMed]

45. Zhang, Y.; He, S.; Bonneil, É.; Simpson, B.K. Generation of antioxidative peptides from Atlantic sea cucumber using alcalase versus trypsin: In vitro activity, de novo sequencing, and in silico docking for in vivo function prediction. Food Chem. 2020, 306, 125581. [CrossRef]

46. Zhong, H.; Abdullah; Zhang, Y.; Deng, L.; Zhao, M.; Tang, J.; Zhang, H.; Feng, F.; Wang, J. Exploring the potential of novel xanthine oxidase inhibitory peptide (ACECD) derived from Skipjack tuna hydrolysates using affinity-ultrafiltration coupled with HPLC-MALDI-TOF/TOF-MS. Food Chem. 2021, 347, 129068. [CrossRef] [PubMed] 